Crop yield, root growth, and nutrient dynamics in a conventional and three organic cropping systems with different levels of external inputs and $\mathbf{N}$ re-cycling through fertility building crops

Thorup-Kristensen, Kristian; Dresbøll, Dorte Bodin; Kristensen, Hanne Lakkenborg

Published in:

European Journal of Agronomy

DOI:

10.1016/j.eja.2011.11.004

Publication date:

2012

Document version

Early version, also known as pre-print

Citation for published version (APA):

Thorup-Kristensen, K., Dresbøll, D. B., \& Kristensen, H. L. (2012). Crop yield, root growth, and nutrient dynamics in a conventional and three organic cropping systems with different levels of external inputs and $\mathrm{N}$ re-cycling through fertility building crops. European Journal of Agronomy, 37(1), 66-82.

https://doi.org/10.1016/j.eja.2011.11.004 
Provided for non-commercial research and education use. Not for reproduction, distribution or commercial use.

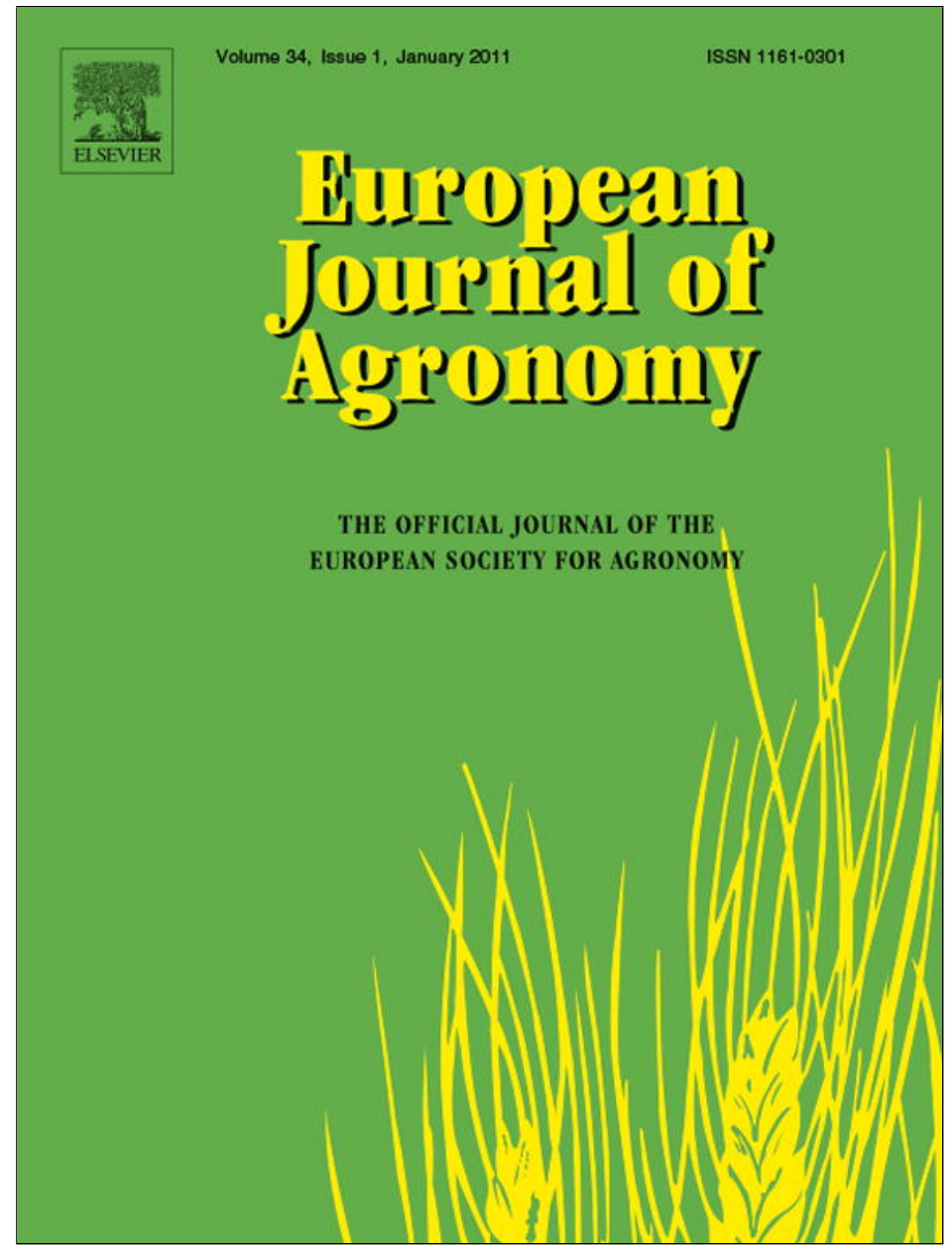

(This is a sample cover image for this issue. The actual cover is not yet available at this time.)

This article appeared in a journal published by Elsevier. The attached copy is furnished to the author for internal non-commercial research and education use, including for instruction at the authors institution and sharing with colleagues.

Other uses, including reproduction and distribution, or selling or licensing copies, or posting to personal, institutional or third party websites are prohibited.

In most cases authors are permitted to post their version of the article (e.g. in Word or Tex form) to their personal website or institutional repository. Authors requiring further information regarding Elsevier's archiving and manuscript policies are encouraged to visit:

http://www.elsevier.com/copyright 


\title{
Crop yield, root growth, and nutrient dynamics in a conventional and three organic cropping systems with different levels of external inputs and $\mathrm{N}$ re-cycling through fertility building crops
}

\author{
Kristian Thorup-Kristensen*, Dorte Bodin Dresbøll ${ }^{1}$, Hanne L. Kristensen \\ Aarhus University, Faculty of Science and Technology, Department of Food Science, Kirstinebjergvej 10, DK-5792 Aarslev, Denmark
}

\section{A R T I C L E I N F O}

\section{Article history:}

Received 8 August 2011

Received in revised form 26 October 2011

Accepted 1 November 2011

\section{Keywords:}

Catch crop

Cover crop

Green manure

Intercrop

Soil nitrogen

Cereals

Vegetable quality

\begin{abstract}
A B S T R A C T
One of the core ideas behind organic production is that cropping systems should be less dependent on import of resources, and minimize negative effects on the surrounding environment compared to conventional production. However, even when clearly complying with regulations for organic production, it is not always obvious that these goals are reached. As an example, strong dependence on import of manure is often seen in current organic production, especially in systems producing high value crops such as vegetable crops.

The aim of the present study was to test novel approaches to organic rotations, designed to reduce the reliance on import of external resources significantly. We compared a conventional system (C) and an organic system relying on manure import for soil fertility (01) to two novel systems (02 and 03 ) all based on the same crop rotation. The $\mathrm{O} 2$ and $\mathrm{O} 3$ systems represented new versions of the organic rotation, both relying on green manures and catch crops grown during the autumn after the main crop as their main source of soil fertility, and the 03 system further leaving rows of the green manures to grow as intercrops between vegetable rows to improve the conditions for biodiversity and natural pest regulation in the crops. Reliance on resource import to the systems differed, with average annual import of nitrogen fertilizers of $149,85,25$ and $25 \mathrm{~kg} \mathrm{Nha}^{-1}$ in the C, 01, 02 and $\mathrm{O} 3$ systems, respectively.

As expected, the crop yields were lower in the organic system. It differed strongly among crop species, but on average the organic crops yielded c. $82 \%$ of conventional yields in all three organic systems, when calculated based on the area actually grown with the main crops. In the $\mathrm{O} 3$ system some of the area of the vegetable fields was allocated to intercrops, so vegetable yields calculated based on total land area was only $63 \%$ of conventional yields.

Differences in quality parameters of the harvested crops, i.e. nutrient content, dry matter content or damages by pests or diseases were few and not systematic, whereas clear effects on nutrient balances and nitrogen leaching indicators were found. Root growth of all crops was studied in the $\mathrm{C}$ and $\mathrm{O} 2$ system, but only few effects of cropping system on root growth was observed. However, the addition of green manures to the systems almost doubled the average soil exploration by active root systems during the rotation from only $21 \%$ in $\mathrm{C}$ to $38 \%$ in $\mathrm{O} 2$ when measured to $2.4 \mathrm{~m}$ depth. This relates well to the observed differences in subsoil inorganic $\mathrm{N}$ content $\left(\mathrm{N}_{\text {inorg }}, 1-2 \mathrm{~m}\right.$ depth) across the whole rotation (74 and $61 \mathrm{~kg} \mathrm{Nha}^{-1}$ in $\mathrm{C}$ and $\mathrm{O} 1 \mathrm{vs}$. only 22 and $21 \mathrm{~kg} \mathrm{Nha}^{-1}$ in $\mathrm{O} 2$ and $\mathrm{O} 3$ ), indicating a strongly reduced $\mathrm{N}$ leaching loss in the two systems based on fertility building crops (green manures and catch crops). In short, the main distinctions were not observed between organic and conventional systems (i.e. C vs. O1, $\mathrm{O} 2$ and $\mathrm{O3}$ ), but between systems based mainly on nutrient import vs. systems based mainly on fertility building crops ( $\mathrm{C}$ and $\mathrm{O} 1 \mathrm{vs.} \mathrm{O} 2$ and $\mathrm{O} 3$ ).
\end{abstract}

(C) 2011 Elsevier B.V. All rights reserved.

\footnotetext{
* Corresponding author. Current address: University of Copenhagen, Faculty of Life Sciences, Department of Agriculture and Ecology Højbakkegård Allé 13, DK-2630 Taastrup, Denmark. Tel.: +45 3533 2216; fax: +453533 3478 .

E-mail address: ktk@life.ku.dk (K. Thorup-Kristensen).

1 Current address: University of Copenhagen, Faculty of Life Sciences, Department of Agriculture and Ecology Højbakkegård Allé 13, DK-2630 Taastrup, Denmark.
}

\section{Introduction}

It is often discussed and studied whether organic production methods are better for the environment (e.g. Birkhofer et al., 2008; Aronsson et al., 2007) or produce higher quality food than conventional methods (e.g. Dangour et al., 2009). However, answering such questions is difficult for several reasons. One is that organic and conventional productions are not well defined methods; they 
can both be performed in very different ways. In any comparison a specific approach to organic production is compared to a specific approach to conventional production. In some studies the focus has been to compare conventional with organic livestockbased and biodynamic systems as in the DOK trials (Mäder et al., 2002; Bosshard et al., 2009). Here a main difference was that fresh and composted animal manures were used in the organic and biodynamic systems, respectively, whereas mineral fertilizer was used in the conventional. Another recent approach is the Nafferton organic rotation experiment (e.g. Leifert et al., 2007; Eyre et al., 2009), where comparisons were made not only between organic and conventional systems, but between all combinations of organic vs. conventional plant protection, nutrient management and rotations optimized for organic or conventional production, in order to investigate which of these factors are primarily responsible for differences in productivity, environmental effects or product quality. Other studies of organic cereal rotations have focused on the use of animal vs. green manures (Torstensson et al., 2006; Aronsson et al., 2007; Doltra et al., 2011). However, though these experiments were very different in their approach, they were all aimed to investigate methods that were already in common use in organic production. Thus, there is a need to investigate new methods to improve organic production.

In practical farming, there is a tendency that organic production methods become more like conventional methods with increased reliance on input factors. In some countries it is allowed to use animal manure from conventional farms and other nutrient rich residues originating from conventional farming systems. This way the reliance on fertility building crops and diversified crop rotations for proper nutrient husbandry is decreased in the organic systems, but this decouples the biogeochemical cycles of carbon and $\mathrm{N}$ (i.e. less co-flow of $\mathrm{C}$ and $\mathrm{N}$ cycles) with possible increase of $\mathrm{N}$ losses from the production (Tonitto et al., 2006; Gardner and Drinkwater, 2009). While such a development may in the short term help organic farms to supply the market demand and to be commercially viable, it may in the longer term undermine consumer confidence if organic farming is not seen to deliver the really different, sustainable, and environmentally friendly alternative to conventional farming. In addition, national regulations may change so that less conventional input is allowed in to organic production, which will lead to an increased demand for improved nutrient management and robust growing systems.

Conventional farming is developing production methods with focus on quality and environment (e.g. Jayasundara et al., 2007), and for organic farming to continue to differentiate from that of conventional, organic farming needs to develop too to ensure high quality products and sustainable cropping systems. In addition the productivity needs to increase in order to be commercially viable and to meet the increasing global demands for food production.

Fertility building crops are management tools to reduce the need for external $\mathrm{N}$ inputs and losses to the environment, like legume green manures that increase $\mathrm{N}$ input through atmospheric $\mathrm{N}$ fixation (Thorup-Kristensen et al., 2003), and autumn N catch crops that increase $\mathrm{N}$ re-cycling by uptake and mineralization at optimized management strategies (Thorup-Kristensen, 2006b; Tonitto et al., 2006; Thorup-Kristensen and Dresbøll, 2010). A major problem is that green manure crops often are grown the whole growing season and thereby reduce the possibility to grow main crops. Short term green manure strategies using only the autumn after main crop harvest may be quite effective (Thorup-Kristensen, 2006b; Sørensen and Thorup-Kristensen, 2003), and they allow green manures to be grown much more frequently in the rotation and at lower cost. Intercrops are living mulches that are grown together with the main crops. Intercrops may have positive effects on pest and weed management (Vanek et al., 2005; Jones and Sieving, 2006), and on nutrient cycling when main crop/intercrop competition is controlled (Liedgens et al., 2004; Båth et al., 2008). The question is how the combined and optimized use of these fertility building crops affects the performance of an organic crop rotation in terms of crop yields and nutrient dynamics?

In this study we aimed at a new approach to organic vegetable crop production, with reduced need for external inputs, decreased nutrient losses to the environment and improved natural pest regulation in the field, while also maintaining high crop yields. Two such systems were developed, and compared to a conventional system and an organic system mimicking modern organic production systems which rely on high conventional nutrient import. The main crop rotation was identical in the four systems, but they varied strongly in nutrient import and in the use of fertility building crops like autumn $\mathrm{N}$ catch crops, green manures and intercrops.

A number of factors in terms of crop growth, product quality, nutrient dynamics, and insect pest dynamics in the experiment were studied as part of the interdisciplinary project VegQure (http://www.icrofs.org/Pages/Research/darcoflII_vegqure.html). This paper concerns the agronomic and environmental results from the experiment in terms of crop shoot and root growth, yield, pest and disease damage to vegetable products, nutrient uptake and nitrogen dynamics measured to $2.5 \mathrm{~m}$ soil depth. Results concerning the other factors will be published elsewhere.

\section{Materials and methods}

\subsection{Field site}

Four cropping systems were grown at the Research Centre Aarslev $\left(10^{\circ} 27^{\prime} \mathrm{E}, 55^{\circ} 18^{\prime} \mathrm{N}\right)$ in Denmark in the period $2006-2009$. The soil was a sandy loam (Typic Agrudalf) with the $0-0.5 \mathrm{~m}$ soil layer containing $1.0 \%$ C, $13 \%$ clay, $15 \%$ silt and $70 \%$ sand; the $0.5-$ 1 m layer containing $0.2 \%$ C, $18 \%$ clay, $13 \%$ silt and $68 \%$ sand and the 1-2.5 m layer containing $0.1 \%$ C, $18 \%$ clay, $14 \%$ silt and $68 \%$ sand. The $\mathrm{pH}_{\mathrm{CaCl} 2}$ was 6.7, 5.9 and 7.3; the content of phosphorous (P) was 23,19 and $16 \mathrm{mg} \mathrm{kg}^{-1}$ and of potassium (K) was 115,98 and $105 \mathrm{mg} \mathrm{kg}^{-1}$ in the $0-0.5,0.5-1$ and $1-2.5 \mathrm{~m}$ layers, respectively ( $\mathrm{P}$ extracted with $0.5 \mathrm{M} \mathrm{NaHCO}_{3}$, K extracted with $\mathrm{CH}_{3} \mathrm{COONH}_{4}$ ). Weather conditions were recorded at a meteorological station at the research centre. During the period from 2006 to 2009 the average annual precipitation at the site was $754 \mathrm{~mm}$ and the average air temperature was $9.2^{\circ} \mathrm{C}$.

The fields had been managed according to organic farming practice with no use of pesticides or inorganic fertilizers since 1996 prior to the initiation of the crop rotation experiment. In 2005 spring barley with undersown clovergrass was grown across all the fields, but after harvest, the clover grass was killed by spraying with glyphosate in system $C$, and by repeated autumn tillage in system $\mathrm{O} 1$ (system identification is outlined in Table 1). In the $\mathrm{O} 2$ system the clover grass was incorporated late autumn before winter rye and in the spring before the other crops. The same procedure was followed in the 03 system except before the vegetables, where row intercrops were established according to the method described below.

\subsection{Experimental design and the four cropping systems}

The experiment included four cropping systems (Table 1) grown in a randomized complete block design with three replicates. The rotations in the four cropping systems were identical in terms of rotation of main crops of cereals and vegetables, but varied in the growing of green manure and catch crops in the autumn after main crop harvest, in management, and in the import and use of fertilizers and pest management (Table 2). 
Table 1

Rotation and fertilization of the four cropping systems, the conventional system (C), the import based organic system (O1), the organic system with autumn soil cover (O2) and the organic system with autumn soil cover and intercrops (O3).

\begin{tabular}{|c|c|c|c|c|c|}
\hline & & C & $\mathrm{O} 1$ & $\mathrm{O} 2$ & $\mathrm{O} 3$ \\
\hline System & & Conventional & Organic - Import based & $\begin{array}{l}\text { Organic - Autumn } \\
\text { soil cover }\end{array}$ & $\begin{array}{l}\text { Organic - Autumn soil cover } \\
\text { and intercrops }\end{array}$ \\
\hline Fertilizer & & NPK fertilizer & Slurry & Slurry & Slurry \\
\hline Mean $\mathrm{N}$ addition $\left(\mathrm{kg} \mathrm{Nha}^{-1}\right)$ & 149 & 88 & 26 & 26 & \\
\hline \multirow[t]{3}{*}{ Field 1} & Oats & & & & \\
\hline & Autumn crop & - & - & Green manure & Green manure \\
\hline & $\mathrm{N}$ addition $\left(\mathrm{kg} \mathrm{N} \mathrm{ha}^{-1}\right)$ & 90 & 47 & 0 & 0 \\
\hline \multirow[t]{3}{*}{ Field 2} & Carrot & & & & \\
\hline & Autumn crop & Winter rye & Winter rye & Winter rye & Winter rye \\
\hline & $\mathrm{N}$ addition $\left(\mathrm{kg} \mathrm{Nha}^{-1}\right)$ & 120 & 56 & 0 & 0 \\
\hline \multirow[t]{3}{*}{ Field 3} & Winter rye & & & & \\
\hline & Autumn crop & _- & - & Green manure & Green manure \\
\hline & $\mathrm{N}$ addition $\left(\mathrm{kg} \mathrm{N} \mathrm{ha}^{-1}\right)$ & 120 & 47 & 0 & 0 \\
\hline \multirow[t]{3}{*}{ Field 4} & Lettuce & & & & \\
\hline & Autumn crop & - & - & Radish catch crop & Radish catch crop \\
\hline & $\mathrm{N}$ addition $\left(\mathrm{kg} \mathrm{Nha}^{-1}\right)$ & 170 & 112 & 0 & 0 \\
\hline \multirow[t]{3}{*}{ Field 5} & Oats & & & & \\
\hline & Autumn crop & - & - & Green manure & Green manure \\
\hline & $\mathrm{N}$ addition $\left(\mathrm{kg} \mathrm{Nha}^{-1}\right)$ & 90 & 47 & 0 & 0 \\
\hline \multirow[t]{3}{*}{ Field 6} & Onion & & & & \\
\hline & Autumn crop & Winter rye & Winter rye & Winter rye & Winter rye \\
\hline & $\mathrm{N}$ addition $\left(\mathrm{kg} \mathrm{Nha}^{-1}\right)$ & 170 & 112 & 70 & 70 \\
\hline \multirow[t]{3}{*}{ Field 7} & Winter rye & & & & \\
\hline & Autumn crop & - & - & Green manure & Green manure \\
\hline & $\mathrm{N}$ addition $\left(\mathrm{kg} \mathrm{Nha}^{-1}\right)$ & 120 & 47 & 0 & 0 \\
\hline \multirow[t]{3}{*}{ Field 8} & White cabbage & & & & \\
\hline & Autumn crop & - & - & $\begin{array}{l}\text { Re-sprouting } \\
\text { cabbage }\end{array}$ & Re-sprouting cabbage \\
\hline & $\mathrm{N}$ addition $\left(\mathrm{kg} \mathrm{Nha}^{-1}\right)$ & 310 & 234 & 140 & 140 \\
\hline
\end{tabular}

One of the systems was grown according to conventional farming methods (C) and the three others according to organic farming methods, but with different approaches. The organic systems were all grown as stockless rotations, but in the first (01) the crop nutrient supply was based on import of slurry, whereas in $\mathrm{O} 2$ and $\mathrm{O} 3$ most of the nutrient supply came from fertility building crops with a much reduced reliance on imported slurry compared to 01. In $\mathrm{O} 2$ and $\mathrm{O} 3$ a catch crop of fodder radish (Raphanus sativus L. var. oleiformis Pers.) was grown after lettuce harvest, and the white cabbage stubble was left growing as a catch crop after cabbage harvest. Furthermore green manures with legumes were sown into the two cereal crops in the spring in $\mathrm{O} 2$ and $\mathrm{O} 3$, and left to grow in the field during the autumn after cereal harvest. In $\mathrm{O} 2$ these green manures were then ploughed into the soil in the early spring prior to establishment of vegetable crops. In $\mathrm{O} 3$ parts of the green manures were left to grow as a row intercrop together with the vegetables. This was done by rotovating $1.3 \mathrm{~m}$ wide bands of green manure into the soil in November to make room for vegetable rows in the next year, but leaving bands of green manure $0.3 \mathrm{~m}$ wide to continue growth in between next year's vegetable crops. Before establishment of the vegetable crops, the bands of green manure were root pruned according to Båth et al. (2008) to remove most of the extensive root system developed by the intercrop in the previous season, and thereby to reduce its competitive effect against the newly established vegetable crops. This was done by a device $0.35 \mathrm{~m}$ wide and working to a depth of c. $0.22 \mathrm{~m}$ which was drawn through the soil. The legumes under sown in oats (Avena sativa L. 'Freddy') were in system $\mathrm{O} 2$ Anthyllis vulneraria L., Medicago lupulina L., Trifolium repens L., Trifolium pratense L. and Lolium perenne L.; and in system O3 Sanguisorba minor Scop. and Lotus corniculatus L. The legumes under sown in winter rye (Secale cereale L. 'Recrut') were in system $\mathrm{O} 2$ Medicago sativa L. and Trifolium pretense L.; and in system $\mathrm{O} 3$ Lotus corniculatus L. and Lolium perenne L.

In $\mathrm{C}, \mathrm{O} 1$ and $\mathrm{O} 2$ all four vegetable crops were grown at a row distance of $0.5 \mathrm{~m}$. In system 03 every third row was an intercrop. The distance between two neighbouring vegetable rows was $0.5 \mathrm{~m}$, whereas a bit more space was allowed for the intercrop giving a distance of $1.1 \mathrm{~m}$ between two vegetable rows across the intercrop. The vegetable crops were carrot (Daucus carota L. 'Bolero'), lettuce (Lactuca sativa L. 'Ardinas'), onion (Alium cepa L. 'Hytech') and white cabbage (Brassica oleracea L. convar. capitata (L.) Alef. var. alba DC 'Impala').

Three replicate blocks were established, each block containing four plots representing the four cropping systems. The plot size was 10 by $130 \mathrm{~m}$. This area was split up into eight fields (10 by $12.5 \mathrm{~m}$ ) representing one replicate crop rotation of each cropping system. The eight fields were kept together in pairs, making four pairs of fields each $25 \mathrm{~m}$ long, kept apart by three areas of $10 \mathrm{~m}$ each for field operations. The four plots (cropping systems) within each replicate block were arranged side by side, separated by $8 \mathrm{~m}$ of land again used for field operations and as border area between the cropping systems.

In short, the crops were managed according to best practice within organic and conventional production. Regarding pest management and fertilization (Table 2) we maintained differences between conventional and organic systems as strictly as possible, as it was exactly the effects of different pest management and fertilization we wanted to study. However, in other aspects of crop management we made a few compromises to avoid that the differences observed were due to factors such as sowing time or planting method where these tend to differ between organic and conventional practice. Thus carrots in all the four systems were sown relatively late as recommended in organic production to avoid the first generation of the carrot root fly, and all onions were established as speedlings with 4-7 plants per pot transplanted into the field, which is normal practise in organic production in Denmark, as opposed to direct sowing used in conventional production.

The crop rotation was an 8-year rotation of oats-carrot-winter rye-lettuce-oats-onion-winter rye-white cabbage. To simplify management, it was organized as a 4-year rotation in the field where the two oat fields were kept together as one larger field, and the same was done with winter rye. Following oat, the field was 
Table 2

gricultural management of the crops grown in the four cropping systems (C, the conventional system; 01, the import-based organic system; O2, the organic system with autumn soil cover; 03, the organic system with autum soil cover and intercrops). Unless indicated for each year, the time point was the same in 2007, 2008 and 2009.

\begin{tabular}{|c|c|c|c|c|c|c|}
\hline \multirow[t]{2}{*}{ Crop } & \multirow[t]{2}{*}{ Treatment } & & \multicolumn{4}{|l|}{ Cropping system } \\
\hline & & & $\mathrm{c}$ & 01 & 02 & 03 \\
\hline \multirow[t]{12}{*}{ Oats } & Soil & Ploughinga & November & November & & \\
\hline & & Incorporation $^{\mathrm{a}}$ & & & March & March \\
\hline & & Rotovator & Mid April & Mid April & Mid April & Mid April \\
\hline & Establishment & Sowing & Mid April & Mid April & Mid April & Mid April \\
\hline & Green manure & Sowing & & & Mid April & Mid April \\
\hline & Fertilizer & Slurry & & Early April & & \\
\hline & & NPK & April & & & \\
\hline & Pests & Tribenuron-methyl + fluroxypyr $(\mathrm{w})^{\mathrm{b}}$ & Mid May (07-08) & & & \\
\hline & & $\operatorname{MCPA}(w)^{c}$ & Early June (07-08) & & & \\
\hline & & $\begin{array}{l}\text { Cyprodinil + } \\
\text { Propiconazol + }\end{array}$ & Early June (07-08) & & & \\
\hline & Harvest & & August & August & August & August \\
\hline & Soil & Harrow & 3 times August/September & 3 times August/September & & \\
\hline \multirow[t]{15}{*}{ Carrot } & Soil & Ploughing & November & November & March & \\
\hline & & Incorporation in rows & & & & Late November \\
\hline & & Loosening of soil & & & & March/April/May \\
\hline & & Rotovator & & & & May \\
\hline & Fertilizer & $\begin{array}{l}\text { Slurry } \\
\text { NPK }\end{array}$ & & April & & \\
\hline & Soil & Root pruning & & & & April \\
\hline & Establishment & Sowing & & May & May & May \\
\hline & 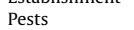 & Linuron (w) & June & & & \\
\hline & & Burn $(w)$ & & May/June & May/June & May/June \\
\hline & & Glyphosat (w) & May/June (08-09) & & & \\
\hline & & Linuron+Aclonifen (w) & June (07) & & & \\
\hline & & Azoxtstrobin (f) & August/September (08-09) & & & \\
\hline & & Pyraclostrobin + Boscalid (f) & August/September (08-09) & & & \\
\hline & & Alpha-cypermethrin (i) & $4-5$ times July/August (08-09) & & & \\
\hline & Harvest & & October & October & October & October \\
\hline \multirow[t]{9}{*}{ Winter rye } & & Ploughing + rotovator & October & October & October & October \\
\hline & Establishment & Sowing & Mid October & Mid October & Mid October & Mid October \\
\hline & Green manure & Sowing & & & April & April \\
\hline & Fertilizer & NPK & Twice March and April & & & \\
\hline & & Slurry & & Early April & & \\
\hline & Pests & Tribenuron-methyl (w) & Late March (07) & & & \\
\hline & & $\mathrm{MCPA}(\mathrm{w})$ & April (08-09) & & & \\
\hline & Harvest & & August & August & August & August \\
\hline & Soil & Harrow & 3 times August/September & 3 times August/September & & \\
\hline \multirow[t]{13}{*}{ Lettuce } & Soil & Ploughing & November & November & March & \\
\hline & & Incorporation in rows & & & & Late November \\
\hline & & Root pruning & & & & Mid April \\
\hline & & Loosening of soil & & & & April/May \\
\hline & & $\begin{array}{l}\text { Rotovator } \\
\text { lant }\end{array}$ & & & & May \\
\hline & Establishment & Planting & Mid May & Mid May & Mid May & Mid May \\
\hline & Fertilizer & NPK & Early May & & & \\
\hline & & Slurry & & April & & \\
\hline & Pests & Alpha-cypermethrin (i) & June (07), May/June (08) & & & \\
\hline & Harvest & & July & July & July & July \\
\hline & Soil & Incorporation & & & July & July \\
\hline & Catch crops & Fodder radish, sowing & & & Early August & Early August \\
\hline & & Harrow & 3 times August/September & 3 times August/September & & \\
\hline
\end{tabular}




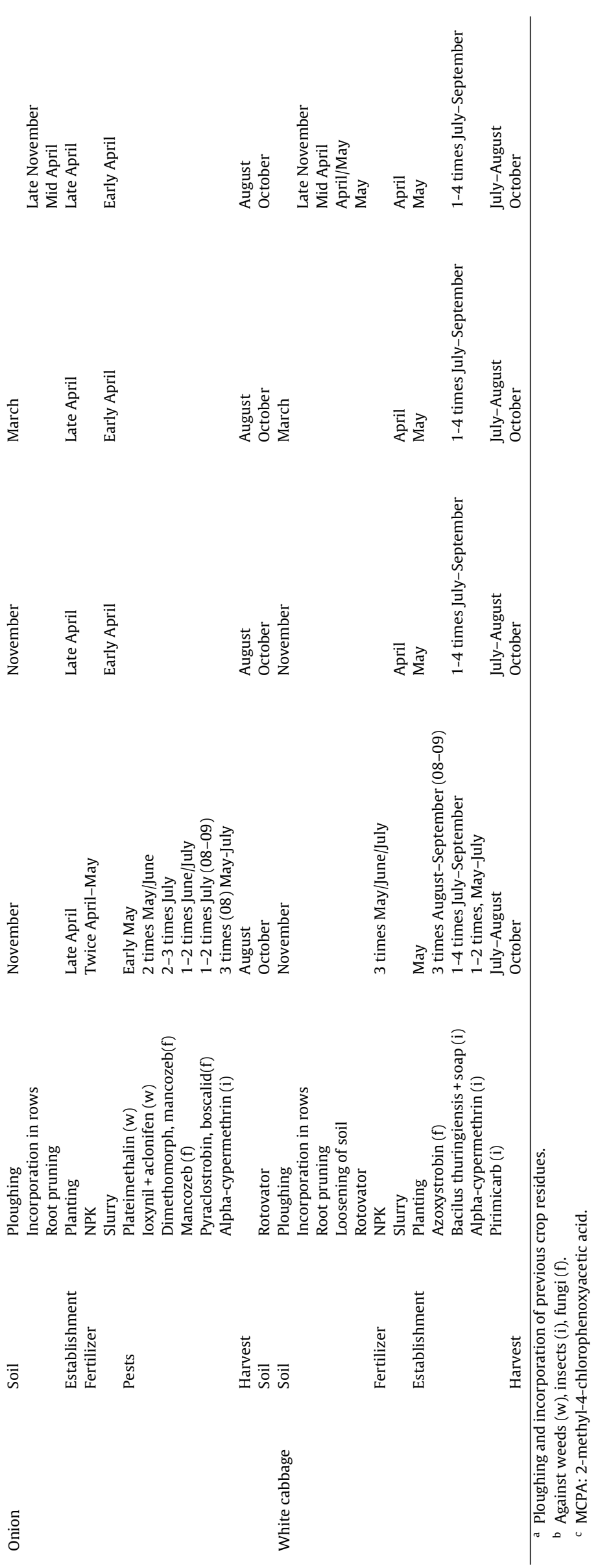

then split into two, one half grown with carrot and one half with onion. After these vegetable crops the two fields was grown as one with winter rye, and then again split and grown with lettuce and white cabbage. All operations of field management are described in Table 2.

\subsection{Root measurements}

Root development and distribution of all crops was measured in the $\mathrm{C}$ and $\mathrm{O} 2$ system, using the minirhizotron method. Root growth of oats, lettuce and white cabbage, and the fertility building crops following oats and lettuce in 02 were measured during 2006 and 2008 , whereas root growth of winter rye, onion, carrot and the fertility building crop following winter rye in the $\mathrm{O} 2$ system were measured during 2007 and 2009.

The minirhizotrons were glass tubes with an outer diameter of $70 \mathrm{~mm}$. For most crops $3 \mathrm{~m}$ long glass tubes were used. The tubes were inserted at an angle of $30^{\circ}$ from vertical, allowing a maximum measurement depth of c. $2.4 \mathrm{~m}$. For onion and lettuce shorter minirhizotron tubes of $1.5 \mathrm{~m}$ length reaching c. $1.2 \mathrm{~m}$ depth were used. Two minirhizotrons were installed in each crop shortly after crop sowing or planting, and consequently for each crop, root growth was measured on a total of 12 minirhizotrons (2 years, 3 replicates, 2 minirhizotrons per plot). In row crops one minirhizotron was installed in the row and one between rows. Further details on the minirhizotron method are found in Kristensen and Thorup-Kristensen (2004).

Along each minirhizotron two counting grids (rows of $40 \mathrm{~mm} \times 40 \mathrm{~mm}$ crosses) were painted on the upper side of the minirhizotron. A mini-video camera was used to record the roots at the minirhizotron surface. Root intensity, as an expression of root density, was calculated as the total number of roots crossing the grid lines in each $40 \mathrm{~mm} \times 40 \mathrm{~mm}$ cross (total of $80 \mathrm{~mm}$ line) and converted to root intensity (root intersections $\mathrm{m}^{-1}$ line). Within each plot the root intensity was then calculated for each soil layer as the average for all grid crosses within the soil layer across the two counting grids on the two minirhizotrons. Rooting depth was recorded as the deepest root observation on each grid, averaged across the two grids on each of the two minirhizotrons within a plot.

Video recording of the minirhizotrons started approximately one month after sowing/planting of each crop, and was repeated every third week during the growth season and the last time close to harvest. From all the recordings rooting depth was estimated, and from the last recording, root intensity was estimated.

\subsection{Plant and soil sampling}

Crop yield was determined by harvest of the 8 fields within each plot, except for border areas within each field, leading to a harvested area of $70-100 \mathrm{~m}^{2}$ per field depending on crop species. Large harvest plots were used, as the harvested crop products were needed for study in other parts of the project. The amount of crop residues was measured on subplots of $1-3 \mathrm{~m}^{2}$ depending on crop species, where all aboveground material was harvested. Samples were kept at $1^{\circ} \mathrm{C}$ until further analysis. Relevant quality grading of each vegetable product in terms of product size, shape, errors or damages by pests or diseases was made. Subsamples of the harvestable product and crop residues were dried $\left(80^{\circ} \mathrm{C}\right.$ for $\left.20 \mathrm{~h}\right)$ for determination of dry matter content and for chemical analysis. On harvestable parts, the contents of N, P and K were determined, and for white cabbage also sulphur (S). On the crop residues only $\mathrm{N}$ content was determined.

Soil sampling for analysis of inorganic $\mathrm{N}$ content $\left(\mathrm{N}_{\text {inorg }}\right)$ were made twice a year to 2.0 or $2.5 \mathrm{~m}$ depth. The first sampling was made in mid May to determine $\mathrm{N}$ availability in the spring, and 
again in mid November to determine the level of unused soil $\mathrm{N}$ at risk of being lost by leaching during winter. To reduce the work load and cost, a reduced sampling plan was made. During 2007 and 2008 soil sampling was made in all fields in the $\mathrm{C}$ and $\mathrm{O} 2$ systems to $2 \mathrm{~m}$ depth, to get results on soil availability and depletion by all crops in the rotations. During 2007, 2008 and 2009 sampling was made to $2.5 \mathrm{~m}$ depth in the lettuce, oat following lettuce and onion fields in all four cropping systems. These three crops were chosen to compare effects of the four systems during the part of the crop rotation where the highest leaching risk was expected. Soil was sampled using a soil piston auger with an inner diameter of $14 \mathrm{~mm}$. Nine replicate samples were combined into one bulk sample for each soil layer and plot. The samples were divided into $0.5 \mathrm{~m}$ depth intervals. The soil samples were frozen until analysis then thawed and subsamples of $100 \mathrm{~g}$ fresh weight were extracted in $1 \mathrm{M} \mathrm{KCl}$ for $1 \mathrm{~h}$ (soil/solution ratio $1: 2$ ). The soil extract was centrifuged and the supernatant was analyzed for $\mathrm{NH}_{4}{ }^{+}$and $\mathrm{NO}_{3}{ }^{-}$content by standard colorimetric methods using an AutoAnalyzer 3 (Bran + Luebbe, Germany). The $\mathrm{N}_{\text {inorg }}$ was determined as the sum of nitrate-N and ammonia-N.

\subsection{Statistical analysis}

Statistical significance of differences in yields and nutrient uptake were averaged over the 3 years and tested by analysis of variance (F-test). Multiple comparisons were based on values of least significant difference (LSD) derived from analyses of variance (Proc GLM, SAS Institute Inc., Cary, NC). The results of pests, diseases and damages were transformed before analysis by the function $y=\log (x+0.8)$ to obtain homogeneity of variance. The value 0.8 was added to avoid observations equal to zero. In assessing differences between results, tests with $P<0.05$ were considered statistically significant.

\section{Results}

\subsection{Yield}

Generally, all plants grew well in all four systems, and the total crop biomass determined as tha ${ }^{-1}$ dry matter was only moderately lower in the organic systems than in the conventional system (Fig. 1 ). On average across all crops, the biomass production of $01, \mathrm{O} 2$ and $\mathrm{O} 3$ was $83 \%, 81 \%$ and $63 \%$ of that in C. All the vegetables in the $\mathrm{O} 3$ system had lower total biomass due to the reduced number of vegetable rows, though the difference between $\mathrm{O} 3$ and the two other organic systems was only significant for carrot and white cabbage. However, if the 03 biomass was corrected to biomass $\mathrm{m}^{-1}$ crop row rather than biomass ha ${ }^{-1}$ the yield did not differ significantly from $\mathrm{C}, \mathrm{O} 1$ or $\mathrm{O} 2$ except in onion. When corrected in this way, the biomass production of 03 was at the same level as in 01 and $\mathrm{O} 2$, and only $81 \%$ of that in C.

Determined as fresh weight of harvest product, the total yield of carrot and white cabbage was similar in the $\mathrm{C}, \mathrm{O} 1$, and $\mathrm{O} 2$ system (Table 3 ). For the onions the conventional system had significantly higher yield than the other systems whereas in lettuce no significant differences were found between $\mathrm{C}$ and $\mathrm{O} 1$ but between $\mathrm{C}$ and the organic systems with catch crops. The marketable yield was higher in the conventional system when growing white cabbage whereas similar marketable yields among systems were seen in carrot and onion (Table 3). In lettuce the marketable yield did not differ between the $\mathrm{C}$ and $\mathrm{O} 1$ system, whereas the $\mathrm{C}$ system differed from $\mathrm{O} 2$ and $\mathrm{O} 3$. The percentage of crops discarded was identical between the cropping systems as was the dry matter percentage when comparing the four cropping systems in any of the crops examined (Table 3 ). The two cereals reacted quite differently, oats

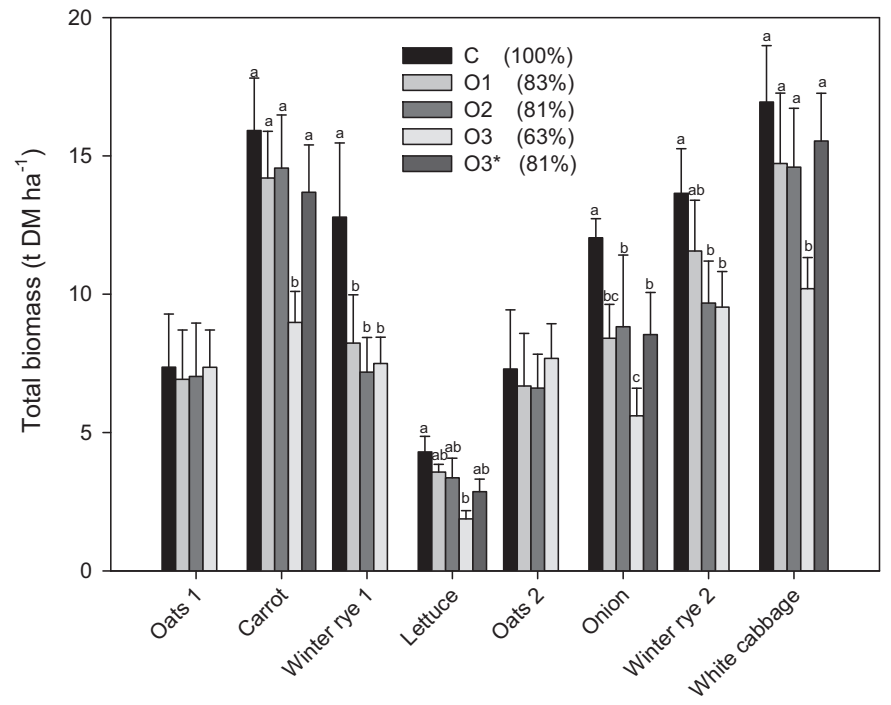

Fig. 1. Total biomass produced in the four cropping systems determined as tha ${ }^{-1}$ dry matter. $3^{*}$ shows the total biomass of the $\mathrm{O} 3$ system when adjusted to identical row meters ha ${ }^{-1}$. Results are means of 3 years and bars show standard deviation. Bars with different letters within each crop are significant different $(P<0.05)$.

showed no yield effects, whereas yield of winter rye was substantially higher in $\mathrm{C}$ than in the $\mathrm{O} 1, \mathrm{O} 2$ and $\mathrm{O} 3$, and the yield reduction in the organic systems was stronger when winter rye followed carrot than when it followed onion (Table 3).

\subsection{Quality}

There was no effect of cropping system on the grading of vegetables in size categories in onion, carrot or white cabbage (Fig. 2). However, in lettuce more large lettuces were produced in the conventional system compared to $\mathrm{O} 2$ and $\mathrm{O} 3$. The $\mathrm{O} 1$ system produced significantly more large lettuces than the $\mathrm{O} 3$ system as well.

The vegetable crops were examined for pests, diseases and damages, and a selection of these is presented in Table 4. Within each of the years significant differences between the systems could be found in some of the parameters determined (Table 5), but when compared as averages over the 3-year period no effect of the variable pest, soil and crop management in the different cropping systems was seen. In some cases the vegetables from the organic systems were more damaged than the conventional vegetables, e.g. damages by rot, slugs, and cabbage white butterfly in white cabbage, watery scales in onion and by scab in carrot. In other cases the conventional vegetables showed higher levels of damages than organic vegetables such as thrips in white cabbage, decay in onion, and branches and green necks in carrots (Table 5).

\subsection{Nutrients}

Differences in nutrient concentrations in the products were quite few, though some effects were observed (Table 6). In carrot, winter rye and oats after white cabbage the crops in the conventional system had significantly higher $\mathrm{N}$ concentration compared to the other systems. In addition, there was a tendency towards a lower $\mathrm{N}$ concentration in all crops in the $\mathrm{O} 3$ cropping system; however, this was only significant for the carrots. No effect of the systems on $\mathrm{P}, \mathrm{K}$ and $\mathrm{S}$ concentrations was found but the concentrations varied considerable between the crops. The total $\mathrm{N}$ uptake in the entire plant was generally also higher in the conventional system than the other systems (Table 3 ).

The effect of cropping system on nutrient uptake in the harvested crop was limited, however, where differences in uptake 
Table 3

The total and marketable yield (fresh weight for vegetables, cereal grain yield is determined at $85 \%$ dry matter), total $\mathrm{N}$ uptake in the whole plant, dry matter percentage and percentage discard determined in the four cropping systems. $03^{*}$ show the results from cropping system 03 when it has been corrected to the same m crop row. Results are means of 3 years and numbers in brackets show the standard deviations. Means followed by different letters within a row are significantly different at $P<0.05$.

\begin{tabular}{|c|c|c|c|c|c|}
\hline & \multicolumn{5}{|c|}{ Cropping system } \\
\hline & $\mathrm{C}$ & 01 & $\mathrm{O} 2$ & $\mathrm{O} 3$ & O3* \\
\hline \multicolumn{6}{|l|}{ Oats after white cabbage } \\
\hline Grain yield $\left(\mathrm{tha}^{-1}\right)$ & $4.5(1.0)$ & $4.6(0.9)$ & $4.6(1.0)$ & $4.8(0.8)$ & \\
\hline Total N uptake $\left(\mathrm{tha}^{-1}\right)$ & $94.3(14.2)$ & $77.3(15.8)$ & $75.1(10.2)$ & $77.4(4.4)$ & \\
\hline \multicolumn{6}{|l|}{ Carrot } \\
\hline Total yield $\left(\mathrm{tha}^{-1}\right)$ & $103.6(7.6) a$ & 93.5 (7.9)ab & $95.1(7.8) \mathrm{ab}$ & $58.7(5.2) \mathrm{c}$ & $89.4 \mathrm{~b}$ \\
\hline Marketable yield ( h ha $^{-1}$ ) & $70.0(20.5) a$ & $66.2(11.7) \mathrm{a}$ & $58.6(9.2) \mathrm{ab}$ & $38.5(3.3) \mathrm{b}$ & $57.2 \mathrm{ab}$ \\
\hline Total N uptake $\left(\mathrm{kg} \mathrm{ha}^{-1}\right)$ & $183(38.0) a$ & $138.4(18.1) b$ & $152.4(17.6) \mathrm{ab}$ & $80.4(7.2) c$ & \\
\hline Dry matter $(\%)$ & $11.9(0.7)$ & $11.9(1.0)$ & $11.9(1.0)$ & $12.0(1.0)$ & \\
\hline Total discard (\%) & $33.3(16.1)$ & $29.7(7.5)$ & $38.5(7.4)$ & $35.9(3.8)$ & \\
\hline \multicolumn{6}{|l|}{ Winter rye after carrot } \\
\hline Grain yield ( $\mathrm{t}$ dw ha $\left.{ }^{-1}\right)$ & $7.8(2.0) \mathrm{a}$ & $4.9(1.0) \mathrm{b}$ & $4.5(0.9) \mathrm{b}$ & $4.6(0.6) \mathrm{b}$ & \\
\hline Total N uptake $\left(\mathrm{tha}^{-1}\right)$ & $144.2(23.6) \mathrm{a}$ & $76.0(8.7) \mathrm{b}$ & $70.2(8.7) \mathrm{b}$ & $69.3(4.5) \mathrm{b}$ & \\
\hline \multicolumn{6}{|l|}{ Lettuce } \\
\hline Total yield $\left(\mathrm{tha}^{-1}\right)$ & $43.4(13.6) a$ & $36.2(12.2) \mathrm{ab}$ & $32.4(7.7) \mathrm{b}$ & $20.0(5.0) c$ & $30.2 \mathrm{a}$ \\
\hline Marketable yield ( $\mathrm{tha}^{-1}$ ) & $39.0(7.4) \mathrm{a}$ & 32.9 (12.7)ab & $29.1(8.7) \mathrm{b}$ & $18.6(6.3) \mathrm{c}$ & $27.2 \mathrm{~b}$ \\
\hline Total $\mathrm{N}$ uptake $\left(\mathrm{kg} \mathrm{ha}^{-1}\right)$ & $114.2(19.5) \mathrm{a}$ & $93.9(9.4) \mathrm{ab}$ & $86.0(9.3) \mathrm{b}$ & $54.9(16.3) \mathrm{c}$ & \\
\hline Dry matter $(\%)$ & $4.3(0.3)$ & $4.5(0.3)$ & $4.7(0.4)$ & $4.6(0.4)$ & \\
\hline Total discard (\%) & $9.0(13.0)$ & $9.3(13.7)$ & $10.2(15.5)$ & 7.5 (9.9) & \\
\hline \multicolumn{6}{|l|}{ Oats after lettuce } \\
\hline Grain yield ( $\mathrm{t}$ dw ha $\left.{ }^{-1}\right)$ & $4.5(1.1)$ & $4.3(1.0)$ & $4.4(0.7)$ & $4.8(0.6)$ & \\
\hline Total N uptake $\left(\mathrm{tha}^{-1}\right)$ & $87.8(22.9)$ & $69.0(9.0)$ & $67.0(8.3)$ & $81.7(15.2)$ & \\
\hline \multicolumn{6}{|l|}{ Onion } \\
\hline Total yield $\left(\mathrm{t} \mathrm{ha}^{-1}\right)$ & 73.8 (13.7)a & $51.8(8.1) \mathrm{bc}$ & $54.0(9.6) \mathrm{b}$ & $34.8(3.6) \mathrm{c}$ & $52.6 a$ \\
\hline Marketable yield ( $\mathrm{tha}^{-1}$ ) & $63.0(18.3)$ & $42.1(9.2)$ & $45.6(13.6)$ & $30.7(3.1)$ & 46.8 \\
\hline Total N uptake $\left(\mathrm{kg} \mathrm{ha}^{-1}\right)$ & $173.2(33.9) \mathrm{a}$ & $106.7(21.9) \mathrm{b}$ & $112.3(39.2) \mathrm{b}$ & $68.4(13.4) \mathrm{b}$ & \\
\hline Dry matter $(\%)$ & $12.8(0.6)$ & $12.4(0.7)$ & $12.5(0.5)$ & $12.7(0.5)$ & \\
\hline Total discard (\%) & $15.1(12.6)$ & $19.1(10.6)$ & $17.0(14.5)$ & $9.8(6.1)$ & \\
\hline \multicolumn{6}{|l|}{ Winter rye after onion } \\
\hline Grain yield ( $\mathrm{t}$ dw ha $\left.{ }^{-1}\right)$ & $8.4(1.5)$ & $6.6(1.0)$ & $6.0(0.9)$ & $5.7(0.8)$ & \\
\hline Total $\mathrm{N}$ uptake $\left(\mathrm{tha}^{-1}\right)$ & $157.5(17.8) a$ & $111.1(13.8) b$ & $101.7(18.5) b$ & $90.5(8.2) b$ & \\
\hline \multicolumn{6}{|l|}{ White cabbage } \\
\hline Total yield $\left(\mathrm{t} \mathrm{ha}^{-1}\right)$ & $98.1(9.2) \mathrm{a}$ & $80.7(12.4) \mathrm{a}$ & $82.0(11.8) \mathrm{a}$ & $56.1(7.7) \mathrm{b}$ & $85.4 a$ \\
\hline Marketable yield ( ha $^{-1}$ ) & $95.9(7.7) \mathrm{a}$ & $77.2(11.1) \mathrm{b}$ & $74.4(11.5) b$ & $47.9(8.2) c$ & $73.0 \mathrm{~b}$ \\
\hline Total N uptake $\left(\mathrm{kg} \mathrm{ha}^{-1}\right)$ & $379.3(40.1) a$ & $309.8(42.9) \mathrm{b}$ & $305.3(32.2) \mathrm{b}$ & $205.6(25.4) \mathrm{c}$ & \\
\hline Dry matter (\%) & $9.9(0.3)$ & $9.9(0.4)$ & $10.0(0.4)$ & $10.2(0.5)$ & \\
\hline Total discard (\%) & $2.2(2.6)$ & $4.1(4.0)$ & $9.2(4.9)$ & $15.0(13.1)$ & \\
\hline
\end{tabular}

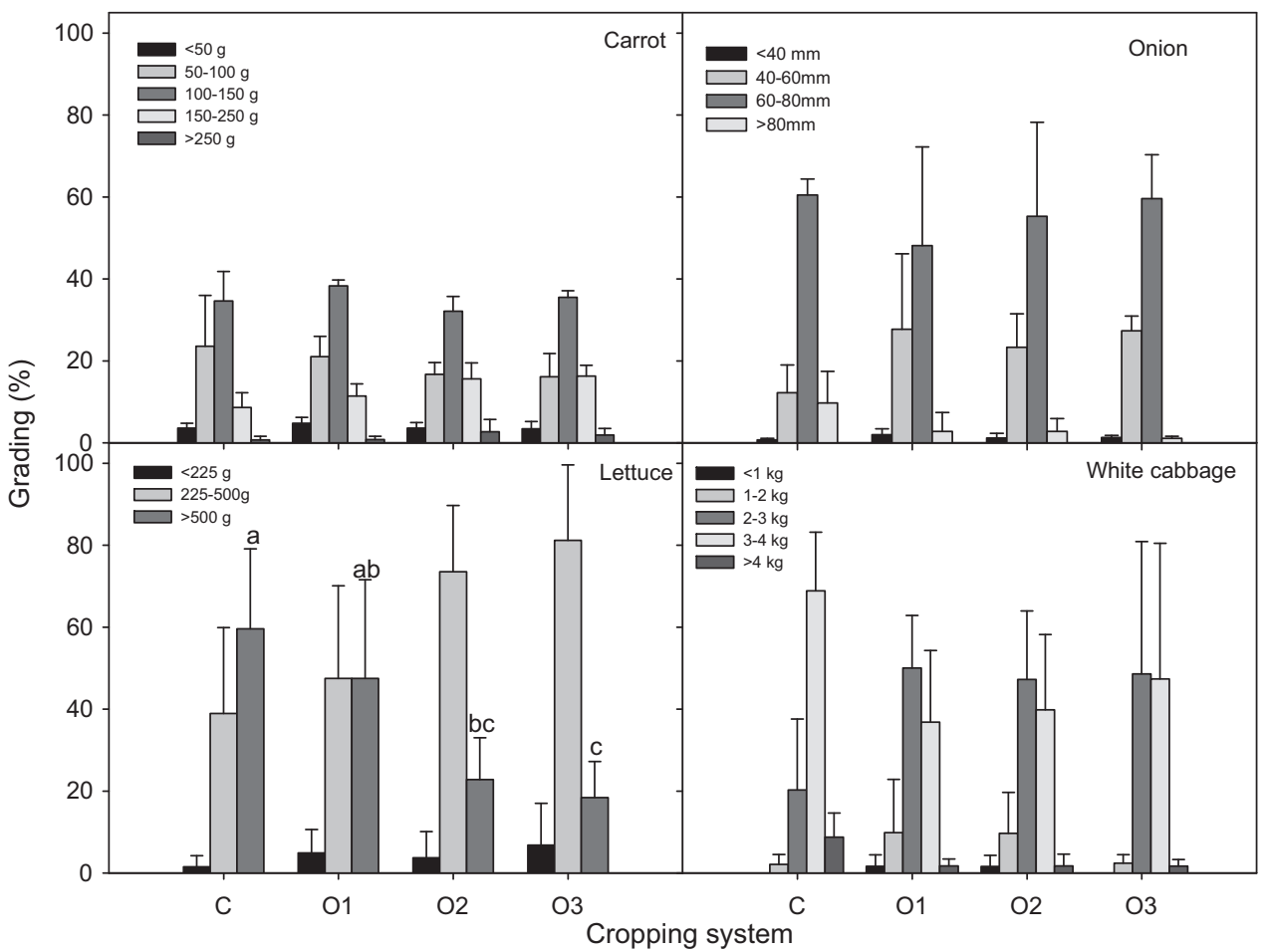

Fig. 2. Size distribution of carrot, onion, lettuce and white cabbage from the four different cropping systems. Results are means of 3 years and bars show standard deviation. Bars with different letters within each size interval are significant different $(P<0.05)$. 
Table 4

Pests, diseases and damages observed in the four vegetable crops. The pests, diseases and damages are only listed if it was observed on more than $1 \%$ of the crops. Results are means of 3 years and numbers in brackets are standard deviations.

\begin{tabular}{|c|c|c|c|c|}
\hline \multirow[t]{2}{*}{ Pests, diseases and damages } & \multicolumn{4}{|c|}{ Cropping system } \\
\hline & $\mathrm{C}(\%)$ & $01(\%)$ & $\mathrm{O} 2(\%)$ & $\mathrm{O} 3(\%)$ \\
\hline \multicolumn{5}{|l|}{ Carrot } \\
\hline Cavity spot & $1.8(2.8)$ & $1.8(2.7)$ & $1.6(2.5)$ & $1.9(2.9)$ \\
\hline Scab & $0.8(0.5)$ & $0.7(0.4)$ & $1.0(0.5)$ & $1.7(1.3)$ \\
\hline Other diseases & $2.3(2.7)$ & $1.4(1.5)$ & $1.5(1.2)$ & $3.0(4.4)$ \\
\hline Carrot root fly & $4.8(5.4)$ & $3.6(2.9)$ & $5.1(5.7)$ & $2.5(2.3)$ \\
\hline Cutworms & $1.0(0.5)$ & $1.2(0.6)$ & $1.6(1.4)$ & $1.8(0.6)$ \\
\hline Mice & $1.7(1.2)$ & $1.5(1.5)$ & $1.9(0.9)$ & $1.6(1.3)$ \\
\hline Branched roots & $6.6(6.5)$ & $4.2(0.7)$ & $5.2(1.3)$ & $3.9(1.3)$ \\
\hline Split roots & $3.9(4.6)$ & $3.2(2.7)$ & $3.9(3.6)$ & $2.9(2.3)$ \\
\hline Cracked roots & $1.4(2.2)$ & $0.6(1.0)$ & $0.6(0.8)$ & $0.7(1.1)$ \\
\hline Broken roots & $2.9(1.1)$ & $1.9(0.7)$ & $2.8(2.1)$ & $2.6(1.8)$ \\
\hline Deform roots & $4.4(1.2)$ & $5.9(1.8)$ & $5.0(1.8)$ & $6.3(0.8)$ \\
\hline Green neck & $5.7(8.9)$ & $1.2(1.0)$ & $1.8(1.1)$ & $0.8(0.1)$ \\
\hline \multicolumn{5}{|l|}{ Lettuce } \\
\hline Tipburn (inside) & $0.6(1.1)$ & 0 & 0 & $2.5(4.3)$ \\
\hline Cracks in leaves & $3.1(5.3)$ & $1.2(2.1)$ & $1.2(2.1)$ & $0.3(0.5)$ \\
\hline Rot (bottom) & $3.7(3.7)$ & $3.7(4.9)$ & $5.2(7.5)$ & $2.5(2.8)$ \\
\hline Undeveloped & $1.5(2.7)$ & $4.9(5.7)$ & $3.7(6.4)$ & $6.8(10.2)$ \\
\hline Ticks & $33.3(57.7)$ & $33.3(57.7)$ & $29.0(50.3)$ & $31.5(54.5)$ \\
\hline Lice (severe) & $4.6(8.0)$ & $13.9(24.1)$ & $24.7(42.8)$ & $9.3(16.0)$ \\
\hline Lice (total) & $24.7(42.8)$ & $32.7(56.7)$ & $33.0(57.2)$ & $29.0(50.3)$ \\
\hline Slugs & 0 & $0.6(1.1)$ & 0 & $1.5(2.7)$ \\
\hline \multicolumn{5}{|l|}{ Onion } \\
\hline Decay & $12.2(16.4)$ & $5.6(4.9)$ & $2.5(2.2)$ & $2.3(2.7)$ \\
\hline Watery scales & $1.0(1.1)$ & $8.1(11.7)$ & $9.8(15.6)$ & $3.6(5.3)$ \\
\hline Dry scales & $1.3(1.2)$ & $3.4(5.1)$ & $2.8(3.8)$ & $2.1(2.9)$ \\
\hline \multicolumn{5}{|l|}{ White cabbage } \\
\hline Rot & $2.1(2.5)$ & $3.2(4.1)$ & $7.9(5.8)$ & $13.2(15.4)$ \\
\hline Cracks in leaves & 0 & $1.1(0.9)$ & $1.6(1.6)$ & $2.1(2.4)$ \\
\hline Thrips (severe attack) & $11.6(10.9)$ & $6.9(6.3)$ & $11.6(7.9)$ & $2.6(4.8)$ \\
\hline Thrips (total) & $70.4(15.9)$ & $67.7(20.1)$ & $72.0(20.4)$ & $51.9(24.3)$ \\
\hline Cabbage root fly (total) & $2.1(2.4)$ & $1.6(1.6)$ & $2.6(3.3)$ & $2.6(3.3)$ \\
\hline Cabbage white butterfly (severe attack) & $1.1(2.1)$ & $4.2(4.4)$ & $7.4(10.1)$ & $2.6(6.3)$ \\
\hline Cabbage white butterfly (total) & $32.8(21.9)$ & $41.8(11.1)$ & $38.1(22.1)$ & $51.9(13.5)$ \\
\hline Slugs & $0.5(0.9)$ & $1.6(2.7)$ & $0.5(0.9)$ & $7.9(13.7)$ \\
\hline
\end{tabular}

Table 5

Examples of year to year variation in selected crops and selected pests or diseases. Results are means of 3 replicates and numbers in bracket show standard deviation. Means followed by different letters within a row are significantly different at $\mathrm{P}<0.05$.

\begin{tabular}{|c|c|c|c|c|c|c|}
\hline \multirow[t]{2}{*}{ Crop } & \multirow[t]{2}{*}{ Pest/disease/damage } & \multirow[t]{2}{*}{ Year } & \multicolumn{4}{|c|}{ Cropping system } \\
\hline & & & C & 01 & $\mathrm{O} 2$ & $\mathrm{O} 3$ \\
\hline \multirow[t]{12}{*}{ White cabbage } & \multirow[t]{3}{*}{ Rot in the top } & 2007 & Oa & $1.6(2.7) \mathrm{a}$ & $3.2(2.7) \mathrm{a}$ & $0 \mathrm{a}$ \\
\hline & & 2008 & $4.8(0) \mathrm{a}$ & $4.8(4.8) \mathrm{a}$ & $11.1(7.3) \mathrm{a}$ & $11.1(11.0) \mathrm{a}$ \\
\hline & & 2009 & $1.6(2.7) \mathrm{b}$ & $3.2(5.5) \mathrm{b}$ & $9.5(4.8) a b$ & $28.6(14.3) \mathrm{a}$ \\
\hline & \multirow[t]{3}{*}{ Slugs } & 2007 & $1.6(2.7) b$ & $4.8(4.8) \mathrm{ab}$ & $1.6(2.7) \mathrm{b}$ & $23.8(14.3) \mathrm{a}$ \\
\hline & & 2008 & Oa & $0 \mathrm{a}$ & $0 \mathrm{a}$ & 0a \\
\hline & & 2009 & $0 \mathrm{a}$ & $0 \mathrm{a}$ & $0 a$ & $0 \mathrm{a}$ \\
\hline & \multirow[t]{3}{*}{ Thrips (severe) } & 2007 & $11.1(7.3) \mathrm{a}$ & $6.3(2.7) \mathrm{a}$ & $14.3(8.2) \mathrm{a}$ & $6.3(7.3) \mathrm{a}$ \\
\hline & & 2008 & $22.2(9.9) a$ & $1.6(2.7) \mathrm{b}$ & $4.8(4.8) \mathrm{b}$ & $\mathrm{Ob}$ \\
\hline & & 2009 & $1.6(2.7) \mathrm{b}$ & $12.7(7.3) \mathrm{a}$ & $15.9(7.3) \mathrm{a}$ & $1.6(2.7) \mathrm{b}$ \\
\hline & \multirow[t]{3}{*}{ Cabbage white butterfly } & 2007 & $49.2(2.7) \mathrm{a}$ & $42.9(8.2) \mathrm{a}$ & $49.2(11.0) \mathrm{a}$ & $57.1(9.5) \mathrm{a}$ \\
\hline & & 2008 & $7.9(5.5) b$ & $30.2(12.0) \mathrm{a}$ & $12.7(2.7) \mathrm{b}$ & $36.5(9.9) a$ \\
\hline & & 2009 & $41.3(19.2) \mathrm{a}$ & $52.4(12.6) \mathrm{a}$ & $52.4(9.5) \mathrm{a}$ & $61.9(19.0) \mathrm{a}$ \\
\hline \multirow[t]{6}{*}{ Onion } & \multirow[t]{3}{*}{ Decay } & 2007 & $0 \mathrm{a}$ & $0 \mathrm{a}$ & $0 \mathrm{a}$ & $0 \mathrm{a}$ \\
\hline & & 2008 & $5.8(2.4) \mathrm{a}$ & $8.3(4.4) \mathrm{a}$ & $3.8(0.5) \mathrm{a}$ & $5.2(2.5) \mathrm{a}$ \\
\hline & & 2009 & 30.9 (14.8)a & $8.6(6.1) b$ & $3.7(1.1) \mathrm{bc}$ & $1.9(0.6) c$ \\
\hline & \multirow[t]{3}{*}{ Watery scales } & 2007 & $2.1(1.1) c$ & $21.6(6.1) \mathrm{a}$ & $27.7(3.2) \mathrm{a}$ & $9.7(4.4) \mathrm{b}$ \\
\hline & & 2008 & $0.7(0.2) \mathrm{a}$ & $2.8(2.8) \mathrm{a}$ & $1.6(1.1) \mathrm{a}$ & $1.1(0.7) \mathrm{a}$ \\
\hline & & 2009 & oa & $0 \mathrm{a}$ & $0 \mathrm{a}$ & oa \\
\hline \multirow[t]{12}{*}{ Carrot } & \multirow[t]{3}{*}{ Scab (Streptomyces scabies) } & 2007 & $1.3(1.5) \mathrm{a}$ & $1.1(1.0) \mathrm{a}$ & $1.2(0.5) \mathrm{a}$ & $1.2(0.9) \mathrm{a}$ \\
\hline & & 2008 & $0.8(0.9) b$ & $0.4(0.2) \mathrm{b}$ & $0.5(0.4) \mathrm{b}$ & $3.1(0.7) a$ \\
\hline & & 2009 & $0.3(0.1) a$ & $0.6(0.9) a$ & $1.4(0.7) a$ & $0.7(0.3) a$ \\
\hline & \multirow[t]{3}{*}{ Green neck } & 2007 & $16.0(8.2) \mathrm{a}$ & $1.8(1.1) \mathrm{b}$ & $1.9(0.8) \mathrm{b}$ & $0.4(0.2) \mathrm{b}$ \\
\hline & & 2008 & $0.8(0.7) a$ & $1.8(1.4) \mathrm{a}$ & $2.8(3.1) \mathrm{a}$ & $1.8(2.2) \mathrm{a}$ \\
\hline & & 2009 & $0.3(0.1) a$ & $0 \mathrm{a}$ & $0.7(0.9) \mathrm{a}$ & $0.2(0.4) \mathrm{a}$ \\
\hline & \multirow[t]{3}{*}{ Split roots } & 2007 & $9.0(1.9) \mathrm{a}$ & $5.6(6.0) a$ & $4.2(1.3) \mathrm{a}$ & $5.1(2.4) a$ \\
\hline & & 2008 & $2.4(0.2) \mathrm{b}$ & $3.8(1.4) \mathrm{b}$ & $7.3(2.6) \mathrm{a}$ & $3.2(1.3) \mathrm{b}$ \\
\hline & & 2009 & $0.2(0.1) a$ & $0.3(0.2) \mathrm{a}$ & $0.2(0.2) a$ & $0.6(0.5) a$ \\
\hline & \multirow[t]{3}{*}{ Branched roots } & 2007 & $14.0(2.0) \mathrm{a}$ & $4.7(4.3) b$ & $3.7(2.1) \mathrm{b}$ & $2.5(0.8) \mathrm{b}$ \\
\hline & & 2008 & $3.8(0.4) a$ & $4.4(1.8) a$ & $5.9(1.2) a$ & $4.8(1.5) \mathrm{a}$ \\
\hline & & 2009 & $2.1(1.2) \mathrm{a}$ & $3.5(1.1) a$ & $6.0(2.9) a$ & $3.6(1.1) a$ \\
\hline
\end{tabular}


Table 6

$\mathrm{N}$ and $\mathrm{S}$ concentration in the main crop of the 8 crops in the crop rotation. $\mathrm{S}$ concentration is only determined in white cabbage. Results are means of 3 replicates in 3 years and statistical significant differences between the four cropping systems are marked with different letters.

\begin{tabular}{|c|c|c|c|c|}
\hline & $\mathrm{C}$ & 01 & $\mathrm{O} 2$ & $\mathrm{O} 3$ \\
\hline \multicolumn{5}{|l|}{$\mathrm{N}(\%)$} \\
\hline Oats after white cabbage & $2.00 \mathrm{a}$ & $1.63 b$ & $1.61 b$ & $1.55 \mathrm{~b}$ \\
\hline Carrot & $0.97 a$ & $0.82 \mathrm{~b}$ & $0.89 b c$ & $0.75 c$ \\
\hline Winter rye after carrot & $1.77 \mathrm{a}$ & $1.47 \mathrm{~b}$ & $1.52 \mathrm{~b}$ & $1.48 \mathrm{~b}$ \\
\hline Lettuce & 3.09 & 2.91 & 2.84 & 2.56 \\
\hline Oats after lettuce & 1.89 & 1.59 & 1.47 & 1.60 \\
\hline Onion & 1.60 & 1.35 & 1.35 & 1.32 \\
\hline Winter rye after onion & $1.78 \mathrm{a}$ & $1.53 \mathrm{~b}$ & $1.61 \mathrm{~b}$ & $1.52 b$ \\
\hline White cabbage & 2.15 & 2.12 & 2.09 & 2.03 \\
\hline \multicolumn{5}{|l|}{$\mathrm{S}(\%)$} \\
\hline White cabbage & 0.69 & 0.68 & 0.61 & 0.64 \\
\hline
\end{tabular}

were observed, the conventional system was superior to the organic systems. In the vegetable crops some variation in the $\mathrm{N}$ uptake was seen whereas no differences between the systems was observed in Pand Kuptake, with the exception of Kuptake in lettuce where the conventional system provided more $\mathrm{K}$ than the organic systems with fertility building crops. In winter rye more $\mathrm{N}$ and $\mathrm{K}$ were taken up in the conventional system as well (Fig. 3).

Differences in nutrient balances (fertilizer input minus crop removal) were mainly governed by differences in fertilizer strategies, as the differences in nutrient removal with harvested products were not large (Table 7). The $\mathrm{O} 3$ and especially $\mathrm{O} 2$ showed clear negative balances for N, P and K. These two systems had the same fertilizer application, but the yields and thereby nutrient removals were higher in $\mathrm{O} 2$. The $\mathrm{O} 1$ also showed negative balance values for $\mathrm{P}$ and $\mathrm{K}$, but not for N. System $\mathrm{C}$ was close to balance, but slightly negative for $\mathrm{K}$ and positive for $\mathrm{N}$ and $\mathrm{P}$.

\subsection{Root distribution and growth}

There were large differences in root distribution under the different crops, from onion which had practically no roots below $0.5 \mathrm{~m}$ to white cabbage and fodder radish which had high root densities all the way to $2.5 \mathrm{~m}$ (Fig. 4). The total root density among main crops increased in the order onion $<$ lettuce $<$ oats $<$ carrot $<$ winter rye $<$ white cabbage. The fodder radish catch crop grown after lettuce in $\mathrm{O} 2$ showed the highest root intensity of all crops in the rotation, and showed high root intensity also in the deepest observed soil layers (Fig. 4a). Green manure growing after harvest of winter rye in $\mathrm{O} 2$ showed root intensities much as those measured on the winter rye crop (Fig. 4d), whereas the root intensity observed on the green manure growing after oats tended to be lower than the root intensity observed on the oats itself (Fig. 4c) and lower than observed on the green manure grown after winter rye.

Differences in root growth between the $\mathrm{C}$ and $\mathrm{O} 2$ systems were limited. Winter rye showed significantly higher root intensity in the $\mathrm{O} 2$ system than in $\mathrm{C}$ whether it was grown after onion or carrot (Fig. 4d), whereas there was a tendency to increased root intensity of white cabbage in the subsoil in the $\mathrm{C}$ system compared to $\mathrm{O} 2$, though this was not significant (Fig. 4a). Winter rye also showed significantly higher root intensity when grown after onions than after carrots.
The average soil exploitation by roots (Table 8 ) showed that most of the soil within the studied soil layer $(0-2.4 \mathrm{~m})$ was unexploited by roots most of the time, but the exploitation was almost twice as extensive in $\mathrm{O} 2(38 \%)$ as in C $(21 \%)$. The difference between the two systems was strongest in the deeper soil layers between 1 and $2.4 \mathrm{~m}$ where $\mathrm{O} 2 \mathrm{had} 27 \%$ root exploitation compared to $12 \%$ in C. As differences in root growth among crops grown in the two systems were quite small, the differences between the systems were due almost exclusively to the presence of fertility building crops in the autumn in $\mathrm{O} 2$, fertility building crops which were not present in C (Fig. 5).

\subsection{Inorganic nitrogen}

Spring $\mathrm{N}_{\text {inorg }}$ values in the topsoil did not tell much about the functioning of the system, mainly because there was a lot of variation in fertilization and crop activity at the time of soil sampling (Fig. 6 ). Winter rye had been growing strongly since the early spring, and also oats had some growth prior to the May soil sampling, whereas among the vegetables only the onions had already been planted but not grown much yet. In $\mathrm{O} 1$ all crops had already received the full amount of slurry, in $\mathrm{O} 2$ and $\mathrm{O} 3$ slurry had been applied to onion and white cabbage plots. In $C$ all but the carrot plots had received fertilizer at the time of the May soil sampling, but some crops had only received part of their fertilizer at the sampling time (Table 2). In the case of carrot no fertilizer had been added to the $\mathrm{C}, \mathrm{O} 2$ or $\mathrm{O} 3$ systems, so the effect of green manure in 02 can be directly compared with the not yet fertilized plots in C (Fig. 6), which shows that topsoil $\mathrm{N}_{\text {inorg }}$ was approximately doubled and below $0.5 \mathrm{~m} \mathrm{~N}_{\text {inorg }}$ was reduced in the $\mathrm{O} 2$ system.

The subsoil $\mathrm{N}_{\text {inorg }}$ in May provide more information about the functioning of the systems, as it was less affected by recent fertilization and early crop growth. In the winter rye plots early growth was likely to have reduced subsoil $\mathrm{N}_{\text {inorg }}$ already, and there were some indications in the results that the application of slurry to the topsoil had already increased subsoil $\mathrm{N}_{\text {inorg. }}$. Subsoil $\mathrm{N}_{\text {inorg }}$ was clearly higher before onion than before carrot in $\mathrm{O} 2$ (Fig. 6), even though the pre-crops were identical, and subsoil $\mathrm{N}_{\text {inorg }}$ before white cabbage was much higher than before lettuce in $\mathrm{O} 2$ again after identical pre-crops.

Table 7

Nutrient application by fertilization and nutrient balance calculated as the difference between what was added with fertilizer and removed by harvested products.

\begin{tabular}{|c|c|c|c|c|}
\hline & $\mathrm{C}\left(\mathrm{kg}\right.$ nutrient ha ${ }^{-1}$ year $\left.^{-1}\right)$ & O1 (kg nutrient ha ${ }^{-1}$ year $\left.^{-1}\right)$ & $\mathrm{O} 2\left(\mathrm{~kg}\right.$ nutrient ha ${ }^{-1}$ year $\left.^{-1}\right)$ & O3 (kg nutrient ha ${ }^{-1}$ year $^{-1}$ ) \\
\hline $\mathrm{N}$ application & 149 & 85 & 25 & 25 \\
\hline $\mathrm{N}$ balance & 32 & 1 & -58 & -38 \\
\hline P application & 28 & 6 & 2 & 2 \\
\hline P balance & 8 & -10 & -15 & -11 \\
\hline K application & 70 & 31 & 9 & 9 \\
\hline K balance & -27 & -50 & -70 & -48 \\
\hline
\end{tabular}




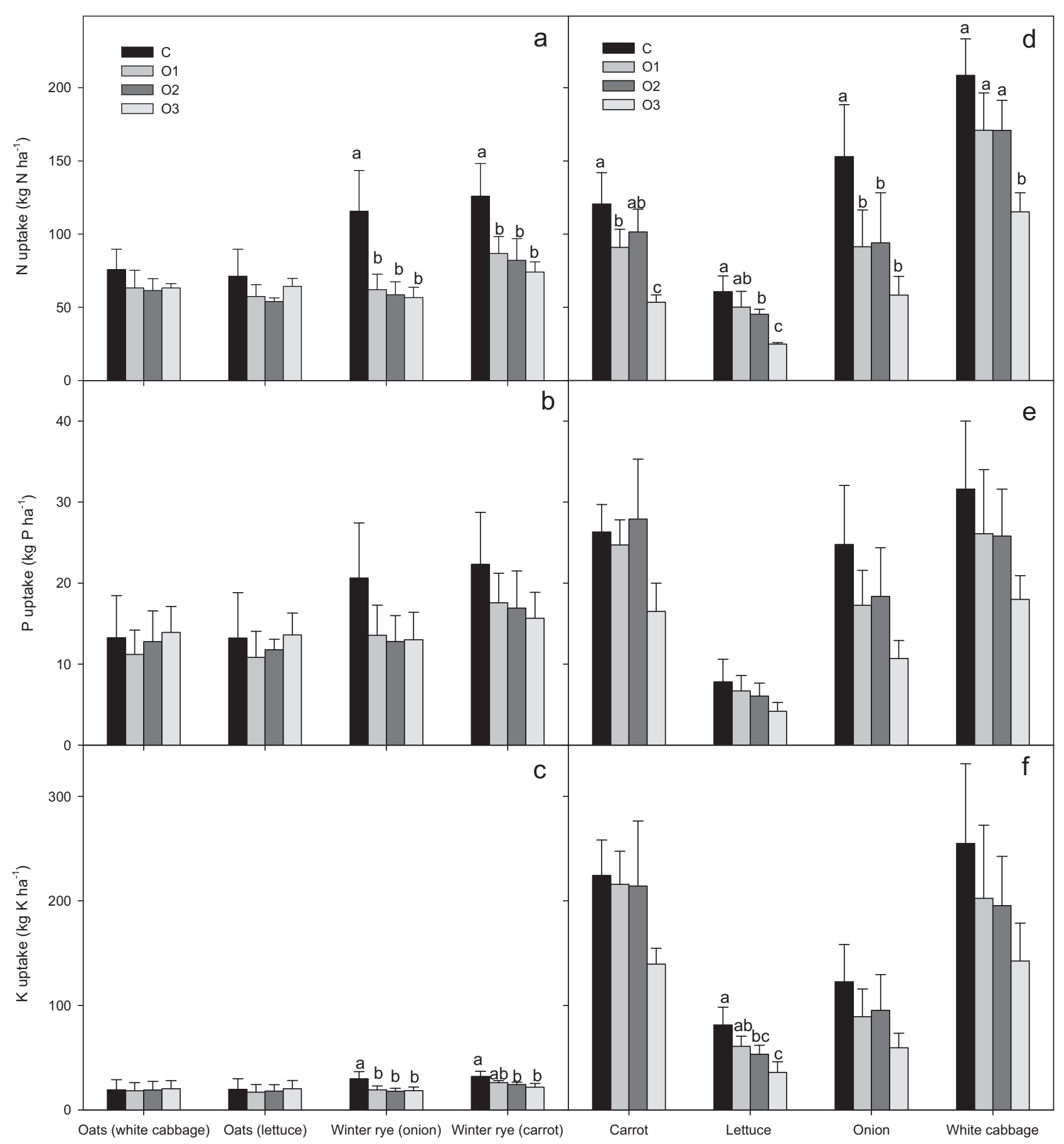

Fig. 3. Nutrient uptake (N, P and K) on harvestable parts of the crops. Results are means of 3 years and bars show standard deviation. Bars with different letters within each crop are significant different $(P<0.05)$.

Before the vegetable crops, i.e. where cereals had been grown the year before, subsoil $\mathrm{N}_{\text {inorg }}$ was generally rather low, in the range of $20-55 \mathrm{~kg} \mathrm{~N} \mathrm{ha}^{-1}$ between 1 and $2 \mathrm{~m}$ depth. In general subsoil $\mathrm{N}_{\text {inorg }}$ was lower in $\mathrm{O} 2$ than in $\mathrm{C}$ (Fig. 6), but the difference was not large.
In May in the cereal plots, subsoil $\mathrm{N}_{\text {inorg }}$ was much more variable from 20 to $130 \mathrm{~kg} \mathrm{~N} \mathrm{ha}^{-1}$. The values were clearly lower in 02 than in $C$, except for winter rye after onion. In general, low values of $30-50 \mathrm{~kg} \mathrm{~N} \mathrm{ha}^{-1}$ were found in the subsoil under winter rye, whereas large variation was found under the young oat crop. Under

\section{Table 8}

Average relative soil exploitation by crop root systems. Data were calculated based on the measured root depths (Fig. 6). A root depth value for each day was obtained by interpolation between the measurement dates. Then the average was calculated across all days in the period March to November, but excluding the winter months where root activity was assumed to be very low.

\begin{tabular}{lllll}
\hline & $0-2.4 \mathrm{~m}$ (\% root occupancy) & $0-1 \mathrm{~m}$ (\% root occupancy) & $1-2.4 \mathrm{~m}$ (\% root occupancy) \\
\hline C & 21 & 30 & 12 & 0.42 \\
O2 & 38 & 49 & 27 & 0.76 \\
\hline
\end{tabular}




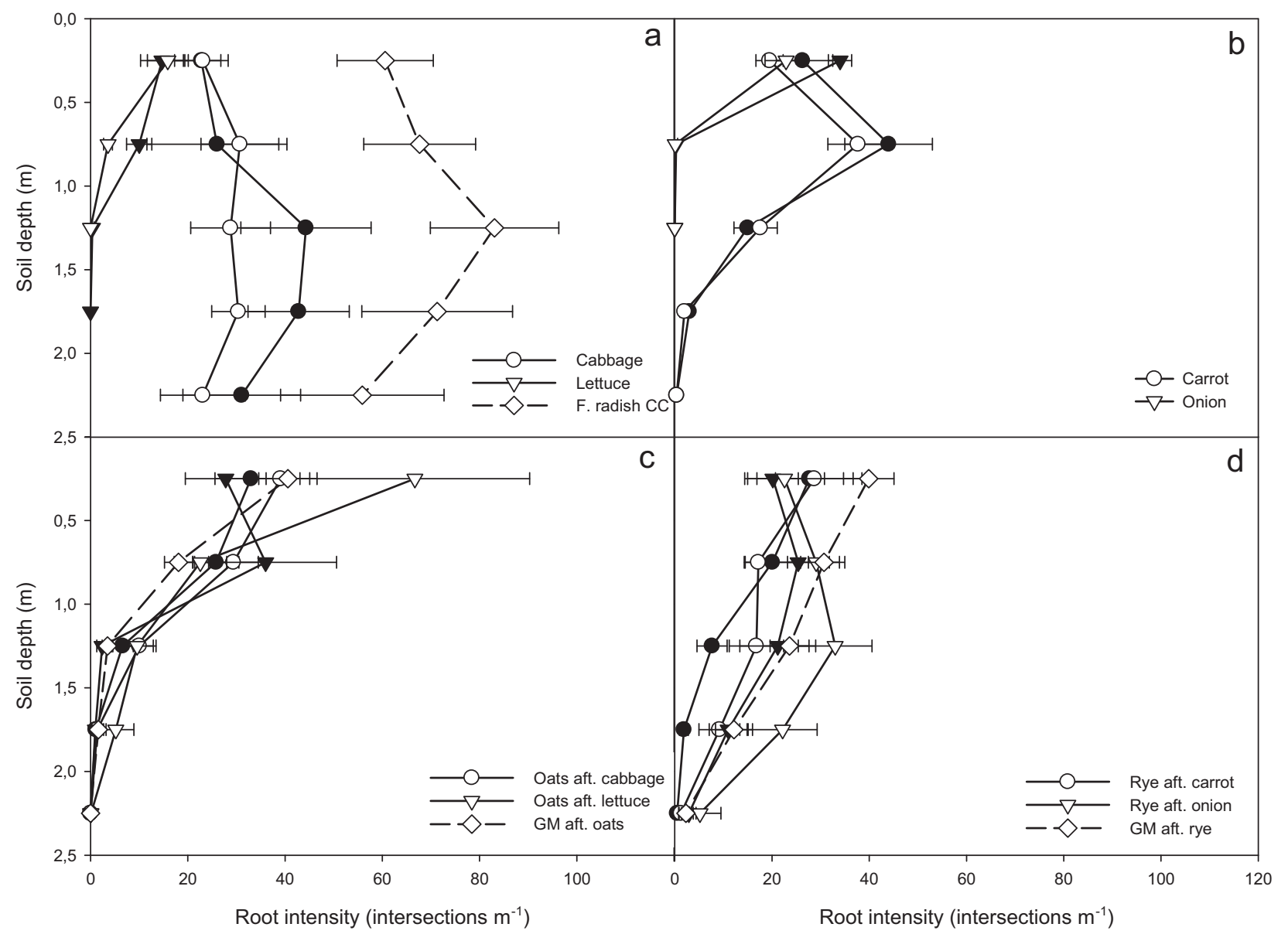

Fig. 4. Root intensity distribution at the end of the growing season of vegetables, cereals and fertility building crops in the rotation from the 02 system (open symbols) and the $\mathrm{C}$ system (closed symbols). Solid lines show main crops, dashed lines with diamond symbols show fertility building crops; fodder radish or green manure (GM). Each point show average of 2 years, with measurements from three plots in each year, error bars show SE.

oats in C very high subsoil $\mathrm{N}_{\text {inorg }}$ values of 90 and $130 \mathrm{~kg} \mathrm{Nha}^{-1}$ were found when oats were grown after white cabbage and lettuce respectively, but in $\mathrm{O} 2$ the values were low at 40 and $20 \mathrm{~kg} \mathrm{~N} \mathrm{ha}^{-1}$ respectively.

In the autumn there were large differences between the $\mathrm{N}_{\text {inorg }}$ in the soil after the vegetable crop species, and also clear differences between the systems. After white cabbage $\mathrm{N}_{\text {inorg }}$ was low both in $\mathrm{C}$ and in $\mathrm{O2}$, and after onion they were high and similar in the two systems. A large difference between the two systems was found after lettuce with very low $\mathrm{N}_{\text {inorg }}$ in $\mathrm{O} 2$ where lettuce was followed by a fodder radish catch crop and very high $\mathrm{N}_{\text {inorg }}$ in $\mathrm{C}$. In all soil layers except the top 0 to $0.5 \mathrm{~m}$ layer, significantly less $\mathrm{N}_{\text {inorg }}$ was

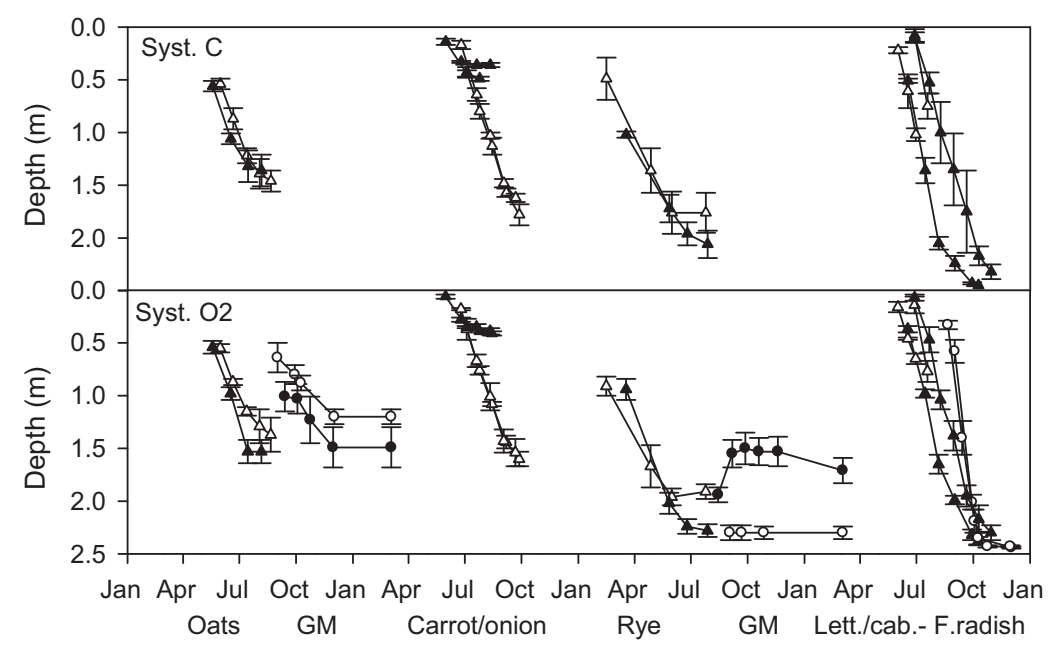

Fig. 5. Rooting depth of main crops and fertility building crops in the $\mathrm{C}$ and $\mathrm{O} 2$ systems. The rotation is shown with an overlay so that year 1 and 5 with oats are shown first, then year 2 and 6 with carrot and onion etc. Main crops are shown with triangles, fertility building crops with circles. Crops in year 1-4 are shown with open symbols while crops in year 5-8 are shown with solid symbols. For each crop results from 2 years are shown with error bars (SE, $n=3)$. 


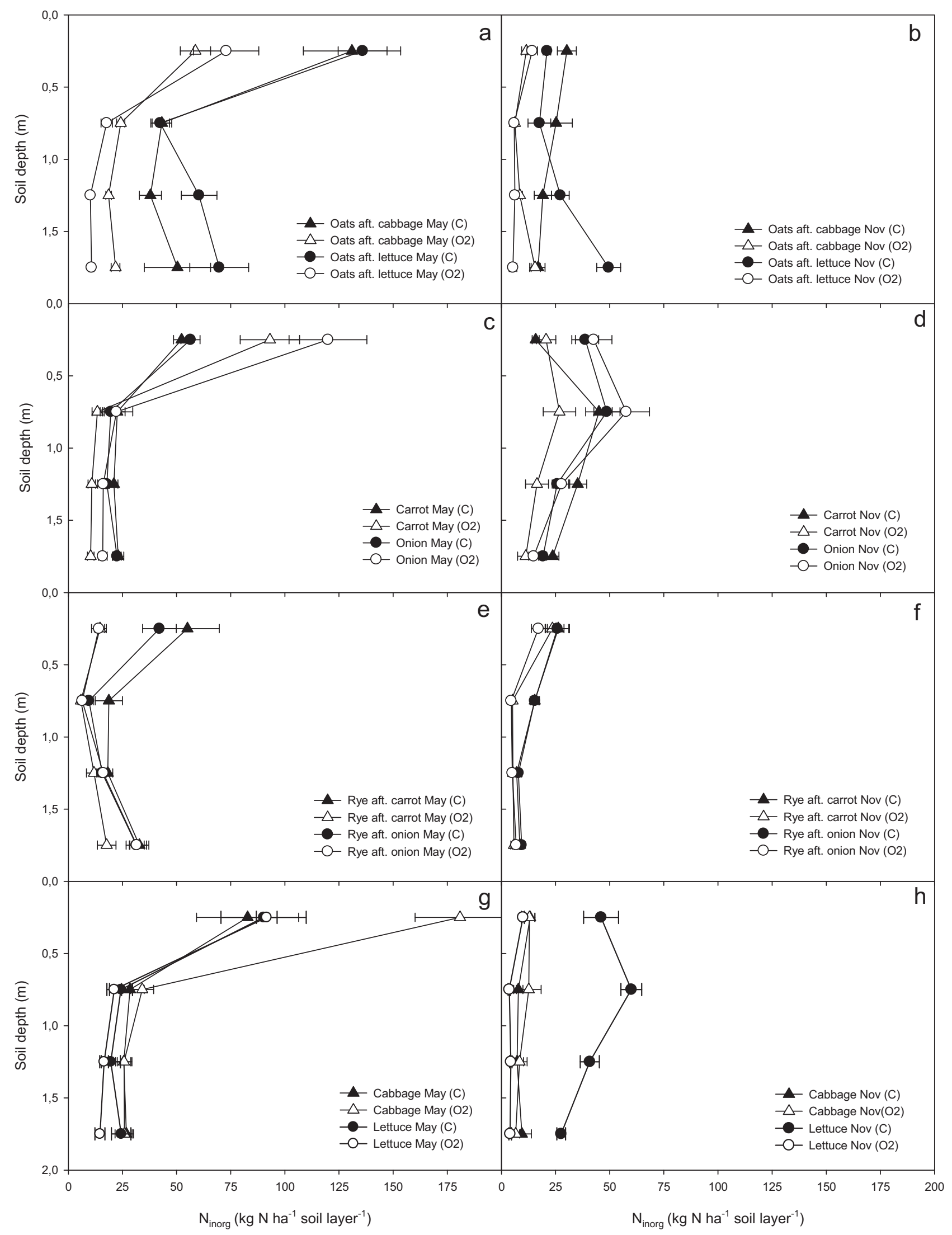

Fig. 6. Profiles of soil $\mathrm{N}_{\text {inorg }}$ in May (a, c, e and g) during early season and November after all crops were harvested (b, d, f and h) in the C (filled symbols) and O2 (open symbols) systems. Results are averages from the 2 years 2008 and 2009, error bars show SE. 


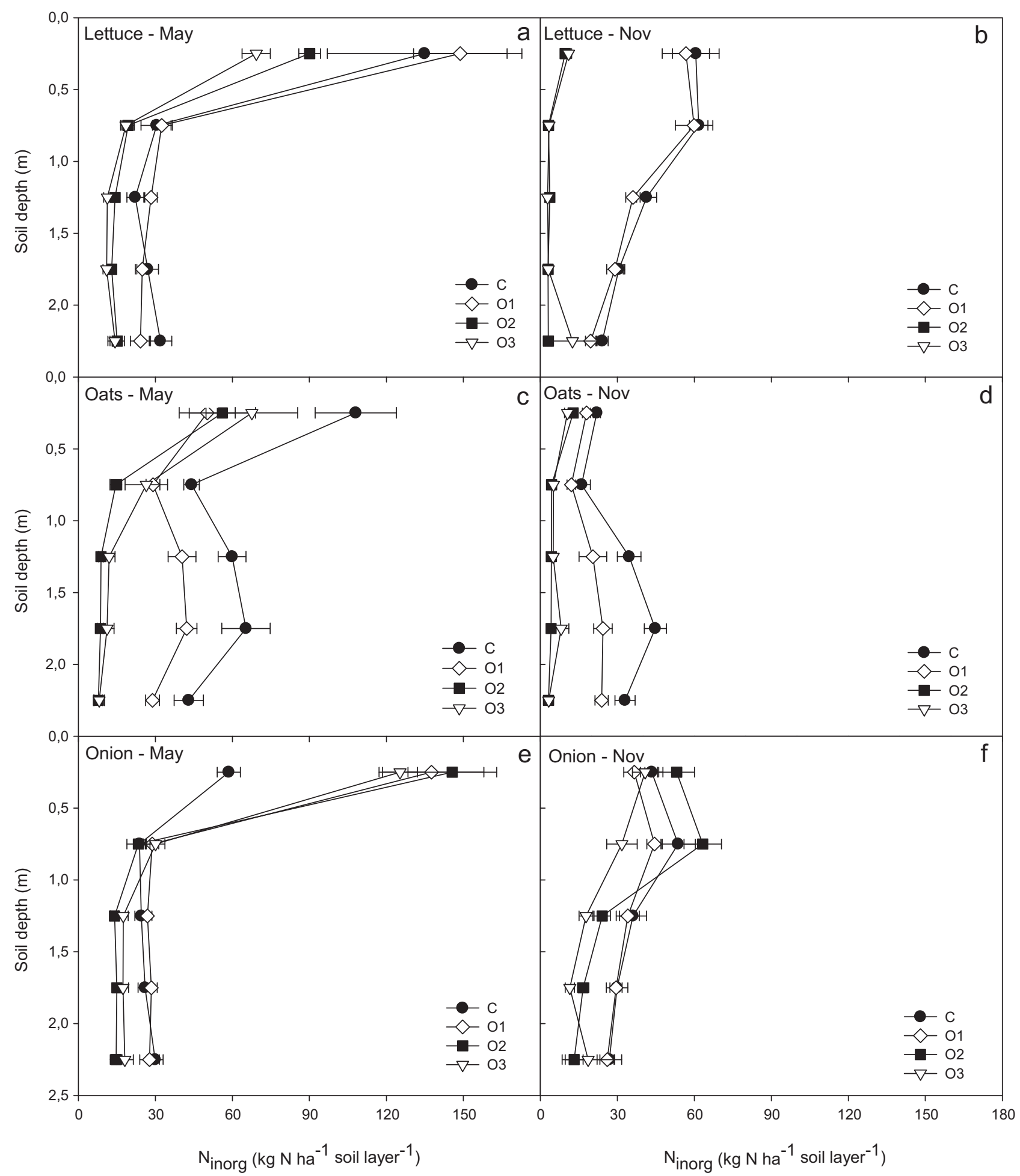

Fig. 7. Profiles of soil $\mathrm{N}_{\text {inorg }}$ in May (a, c and e) during early season and November after all crops were harvested (b, d and f) during the lettuce-oats-onion sequence of the four cropping systems. Results are from the 3 years 2008, 2009 and 2010, error bars show SE.

found in $\mathrm{O} 2$ than in $\mathrm{C}$ after carrots as well. After the cereals $\mathrm{N}_{\text {inorg }}$ was relatively low and except from the top $0.5 \mathrm{~m}$ soil layer after winter rye it was always significantly lower in $\mathrm{O} 2$ than in $\mathrm{C}$. The only somewhat higher $\mathrm{N}_{\text {inorg }}$ value after cereals was observed after oats following lettuce in the $\mathrm{C}$ system.

Comparing soil $\mathrm{N}_{\text {inorg }}$ of all four systems during a shorter sequence of the rotation showed that the systems could be paired according to their main effects on soil $\mathrm{N}_{\text {inorg }}$; $\mathrm{C}$ and $\mathrm{O} 1$ showed one type of results, $\mathrm{O} 2$ and $\mathrm{O} 3$ another (Fig. 7). On average across all measurements, $\mathrm{N}_{\text {inorg }}$ in the $0-2 \mathrm{~m}$ soil layer was 184 and $170 \mathrm{~kg} \mathrm{Nha}^{-1}$ in $\mathrm{C}$ and $\mathrm{O} 1$ which was not significantly different, but was significantly higher than the 104 and $95 \mathrm{~kg} \mathrm{~N} \mathrm{ha}^{-1}$ found in $\mathrm{O} 2$ and $\mathrm{O} 3$ (Fig. 8). In the subsoil layer (1-2 $\mathrm{m}$ depth) the similar average values were $74,61,22$ and $21 \mathrm{~kg} \mathrm{~N} \mathrm{ha}^{-1}$ respectively, again $\mathrm{C}$ and $\mathrm{O} 1$ were significantly higher than $\mathrm{O} 2$ and $\mathrm{O} 3$. In both spring and autumn, subsoil $\mathrm{N}_{\text {inorg }}$ was significantly higher in $\mathrm{C}$ and $\mathrm{O} 1$ than in $\mathrm{O} 2$ and $\mathrm{O} 3$. Generally the $\mathrm{O} 2$ and $\mathrm{O} 3$ systems had almost identical soil $\mathrm{N}_{\text {inorg }}$ levels. Also $\mathrm{C}$ and $\mathrm{O} 1$ showed rather similar $\mathrm{N}_{\text {inorg }}$ 


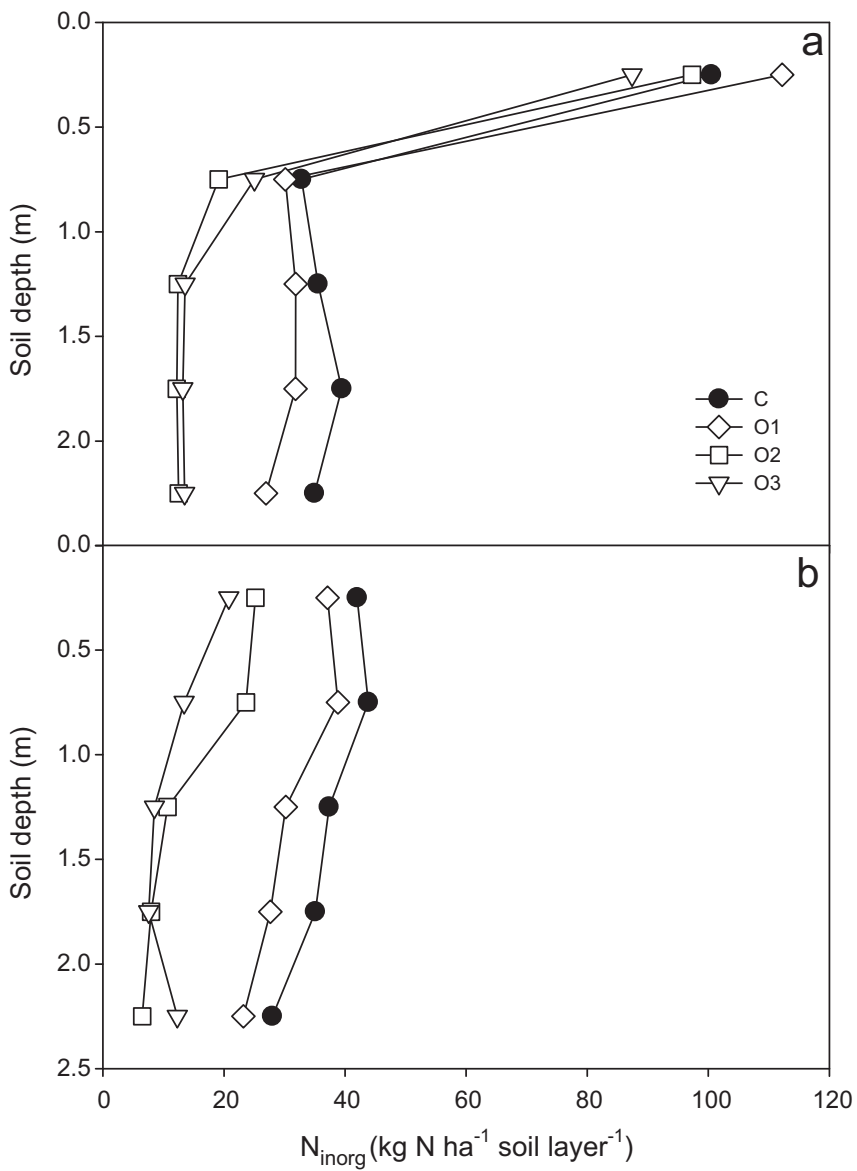

Fig. 8. Profiles of soil $\mathrm{N}_{\text {inorg }}$ in May (a) and November (b) on average of all data measured in the lettuce-oats-onion sequence of the rotations during 2008, 2009 and 2010.

distribution, though $\mathrm{N}_{\text {inorg }}$ was significantly higher in $\mathrm{C}$ than in $\mathrm{O} 1$ $(P<0.05)$. In the years of the lettuce and onion crops very little difference was found except in the topsoil in the spring before onions due to early slurry application in 01 . Before and after the oat crop soil $\mathrm{N}_{\text {inorg }}$ was clearly higher in $\mathrm{C}$ than in $\mathrm{O} 1$, but they showed the same general depth distribution of $\mathrm{N}_{\text {inorg }}$, and both showed much higher subsoil $\mathrm{N}_{\text {inorg }}$ than $\mathrm{O} 2$ and 03 . Looking specifically at the subsoil, $\mathrm{N}_{\text {inorg }}$ was on average reduced by $18 \%$ in 01 compared to C, but by as much as $71 \%$ in both $\mathrm{O} 2$ and $\mathrm{O} 3$.

\section{Discussion}

\subsection{Autumn crop cover and yields}

The organic systems were found to give only moderate yield reductions compared to the conventional farming system. In 01 the average yield level of the vegetable crops was $83 \%$ of the conventional yield, and in the $\mathrm{O} 2$ system based on fertility building crops the yield level was almost the same with $81 \%$ of conventional yields. The exact yield comparison between cropping systems depend strongly on the choice of crop species for the rotation as shown by the similar yield levels of oats and carrots in the organic and the conventional systems, whereas onion and winter rye showed much larger yield reductions in the organic ( $28 \%$ and $40 \%$ ). Such differences in crop response are generally seen depending on e.g. crop nutrient demand (Dresbøll et al., 2008; Thorup-Kristensen, 1999) and are not mainly an effect of the specific crop rotation here. The vegetable crops in this experiment were chosen to range from very sensitive crops (onion) to crops with low sensitivity to cropping system (carrot), whereas the two cereal crops oats and winter rye were selected based on their performance and their strong competitive ability towards weeds in organic production. In conventional farming, spring barley and winter wheat would have been the typical choice of cereals. It is likely that especially spring barley would have shown larger yield reduction under organic conditions than oats, but as one crop out of six in the rotation, this would not have changed the overall productivity much. As the experiment was established on an area where an unfertilized organic rotation had been grown for the preceding 10 years, the good productivity of the organic crops was not a consequence of recent conventional cropping practices on the area.

The crop yields in the $\mathrm{O} 2$ and $\mathrm{O} 3$ systems where fertilizer input was reduced was very close to the yields of $\mathrm{O} 1$ when the comparison was based on the vegetable yields per $\mathrm{m}$ crop row. In general, there were no clear examples of crops responding differently towards the three organic systems. Similar good effects of catch crop use on yields has been found in organic cereal rotations, however, with continued reliance on high manure inputs, and some differences in response of different crops in rotation (Doltra et al., 2011).

If the comparison was based on vegetable yield per hectare, the yield reductions in $\mathrm{O} 3$ was clearly more substantial compared to 01 and 02, as growing intercrops left less area for the vegetable crops. Whether the comparison to yield per $m$ crop row or yield per hectare land is the most relevant, depend on the situation at the farm. The cost of producing one unit of vegetables will not be much higher with intercrops than without intercrops. Therefore, if the vegetable production at the farm can be maintained by increasing the total vegetable area at the expense of e.g. cereal crops, introducing intercropping systems is economically feasible. However, if the available land area for vegetables is limited, introducing intercrops will reduce the overall vegetable production at the farm, and thereby strongly reduce its income. In this last situation, yield per hectare rather than yield per $\mathrm{m}$ crop row is the most relevant yield parameter.

The fact that vegetable yield per $\mathrm{m}$ crop row was maintained in the 03 system show that the intercropping strategy can be practiced with a moderate extra cost. This was obtained by improved intercropping strategies to control crop-intercrop competition based on species choice for intercrops, root pruning strategies (Båth et al., 2008) and altered spatial field design with intercrops growing between every second vegetable crop row. Most other studies have shown that well developed intercrops will reduce vegetable yield unacceptably (Båth et al., 2008). Intercrop planting had to be delayed until 8 weeks after leek planting (Müller-Schärer, 1996) or seeded 30 days after pumpkin seeding (Vanek et al., 2005) to avoid negative yield effects. A further advantage of the intercrop strategy in the present study was that the intercrops were established already 1 year earlier than the vegetable crops which enhanced their ecological functioning by keeping the soil continuously vegetated during the previous year of cereal production and during the growth season of the vegetables.

\subsection{Product quality and biological pest regulation}

The results confirm that the product quality in the organic systems did not differ significantly from the conventional system or in the comparison between the $\mathrm{O} 1$ system and the $\mathrm{O} 2$ and $\mathrm{O} 3$ systems with fertility building crops. The general product quality parameters (product size, dry matter percentage, $\mathrm{N}$ content and level of damages/discarding) were not generally affected; there were examples of differences between systems in specific years, but the effects were not consistent over the 3 years of the experiment, and some examples pointed to advantages of the organic systems others to advantages of the conventional system. Based on this, the results did not point towards improved biological pest regulation in the $\mathrm{O} 2$ 
and 03 systems, but also that the use of pesticides and fungicides in the conventional system did not reduce pest and disease damage to the products. The year to year variation in climate and management and the variation among quality parameters studied show that such studies must be rather comprehensive; studying only few quality parameters or for too short time may lead to results which are far from representing the performance of the systems and may even lead to wrong conclusions.

However, our results did show some examples of interesting effects of intercropping on vegetable quality (e.g. decrease of thrips attacks in white cabbage and fewer onions with signs of decay and watery scales) and affected factors such as natural regulation of insect pests through effects on insect pathogenic fungi (Meyling et al., 2011) and early season carabid beetle activity and species composition (S. Navntoft and N.V. Meyling, unpublished). Nevertheless, no clear benefits of the intercrops were observed, and they were thereby not able to compensate for even a moderate extra cost in this case. More advantage may be achieved by developing the design of the intercropping system or the species choice. In the present study none of the intercrop species were especially attractive to insects through their production of pollen or nectar in their flowers, but potentially introduction of such species could have a significant effect on insect population dynamics in the crops (Hogg et al., 2011).

\subsection{Reduced nutrient losses to the environment}

The N leaching was not measured directly, but measurements of soil $\mathrm{N}_{\text {inorg }}$ twice a year to 2 or $2.5 \mathrm{~m}$ depth gave detailed information of soil $\mathrm{N}$ dynamics and how much $\mathrm{N}$ leached to the deeper soil layers. As previously shown (Thorup-Kristensen, 2006a; ThorupKristensen et al., 2009) the introduction of fertility building crops may strongly reduce deep soil $\mathrm{N}$ content during the season while the fertility building crop is grown, but the effect may also remain for a longer period, and still be strong in the next autumn/winter season.

As fertility building crops were grown at least every second year and the average presence of active roots in the soil was almost doubled by the inclusion of fertility building crops as done in $\mathrm{O} 2$ and 03 , it is not surprising that a consistently strong reduction of subsoil $\mathrm{N}_{\text {inorg }}$ was observed. On average the subsoil $\mathrm{N}_{\text {inorg }}$ in $\mathrm{O} 2$ and 03 was around $30 \%$ of the levels found in C and O1, indicating strongly reduced $\mathrm{N}$ leaching losses. In many studies of $\mathrm{N}$ leaching, $\mathrm{N}$ leached to below a depth of $1 \mathrm{~m}$ or even less is assumed to be lost by leaching (e.g. Hansen et al., 2010). Management of crop and soil during autumn has been identified as the main determinant of $\mathrm{N}$ leaching in an organic crop rotation with lowest nitrate leaching when a catch crop soil cover during autumn and winter was established (Askegaard et al., 2011). Also Torstensson et al. (2006) found that systems with intensive use of fertility building crops had significantly lower $\mathrm{N}$ leaching loss than other systems, though in their system the fertility building crops were added to a conventional system making this more $\mathrm{N}$ efficient than the organic and other conventional systems. Such results point to fertility building crop strategies being much more important than conventional vs. organic farming systems in optimizing $\mathrm{N}$ utilization and reducing $\mathrm{N}$ leaching losses.

When using average subsoil $\mathrm{N}_{\text {inorg }}$ as an indicator of $\mathrm{N}$ leaching losses from the systems, it is indicated that 01 reduced leaching by $18 \%$ during the most leaching intensive sequence with shallow rooted crops (lettuce, oats, onion), very close to its effects on crop yields. This means, that even though there was a small reduction in leaching per hectare, there was no improvement in leaching loss per unit of food produced. This is similar to results of e.g. Aronsson et al. (2007) who also found that lower N leaching losses per hectare in organic systems did not lead to significantly lower leaching losses per unit crop product. On the other hand, $\mathrm{O} 2$ and $\mathrm{O} 3$ reduced subsoil $\mathrm{N}_{\text {inorg }}$ by $71 \%$ while reducing average yields only by $19 \%$ and $37 \%$ respectively, showing systems where nitrogen leaching per unit food produced is also clearly reduced.

It is noteworthy that the fertility building crop strategies were able to almost double the soil exploitation by crop roots, from $21 \%$ to $38 \%$ of the top $2.4 \mathrm{~m}$ of the soil and more than double the exploitation of the deeper part half of this soil profile from $12 \%$ to $27 \%$. The increased root exploitation in the fertility building crop systems represent a strong change towards a more natural ecosystem system where also the subsoil form an active part of the resource base for plant growth. However, it also illustrates how different even this system is from a natural system where the soil exploitation would be expected to be close to $100 \%$ (Canadell et al., 1996; Sun et al., 1997). Still the results on soil $\mathrm{N}$ and especially soil $\mathrm{N}$ in deeper layers show that this increased root exploitation of the soil has strongly improved the ability of the system to retain $\mathrm{N}$ and avoid that this resource is being lost by leaching, i.e. that a normal function of natural ecosystems has to a significant extent been introduced into a farming system and that the biogeochemical cycles of carbon and $\mathrm{N}$ has been recoupled by the fertility building crop strategies (Tonitto et al., 2006; Gardner and Drinkwater, 2009). Further significant improvement in this aspect of arable cropping systems will require much more dramatic changes to the system, e.g. a shift towards perennial crops (Cox et al., 2010).

This improved soil exploitation was not an effect of improved root growth of the crops in organic compared to conventional systems, as only very few differences were observed in root growth of crops between the $\mathrm{C}$ and $\mathrm{O} 2$ system. Where comparisons were possible, the root growth of the crops was close to previous results (Kristensen and Thorup-Kristensen, 2007; ThorupKristensen, 2006b). Instead it was the addition of the extra element of fertility building crops and their root growth which so strongly improved the soil exploitation of the $\mathrm{O} 2$ system.

Another aspect allowing the development of $\mathrm{N}$ efficient rotations here was the mixed rotation of vegetables and cereal crops. In the spring, subsoil $\mathrm{N}_{\text {inorg }}$ values were relatively low before the vegetables, i.e. after cereal crops, and the highest values were found before oats following lettuce and cabbage. This illustrate that growing cereals as part of a vegetable rotation allow improved $\mathrm{N}$ husbandry. Cereals are typically more efficient in depleting soil $\mathrm{N}_{\text {inorg }}$ than vegetables (Wehrmann and Scharpf, 1979), and as cereals leave crop residues with less $\mathrm{N}$ and higher $\mathrm{C} / \mathrm{N}$ ratios in the field than vegetable crops, they also reduce $\mathrm{N}$ mineralization after harvest. In the winter rye crop $\mathrm{N}_{\text {inorg }}$ was already low in May, even after onion leaving high $\mathrm{N}_{\text {inorg }}$ levels in the autumn, but this $\mathrm{N}_{\text {inorg }}$ had probably already been taken up by the winter rye in the early spring. In a previous study winter wheat was found to take up much soil $\mathrm{N}$ already before mid April under similar conditions (ThorupKristensen et al., 2009), again confirming the typically higher $\mathrm{N}$ efficiency of cereal crops. Finally, cereal crops offer better options for introducing fertility building crops into the system than most vegetables do, as cereals allow undersowing of fertility building crops and because small yield losses caused by their establishment can more easily be tolerated in cereal crops than in vegetables. This was a characteristic which was critical for the design of the present rotation study.

\subsection{Less dependence on nutrient import}

The results showed that strategic use of fertility building crops could strongly reduce the dependence on import of nutrients. While the import of $\mathrm{N}$ in slurry was reduced from $85 \mathrm{~kg} \mathrm{Nha}^{-1}$ year $^{-1}$ in 01 to only $25 \mathrm{~kg} \mathrm{Nha}^{-1}$ year $^{-1}$ in 02 , only few effects were observed in terms of crop $\mathrm{N}$ uptake and content. While all crops were fertilized in 01 , four out of the six crops were 
left without any fertilizer application in 02 , but still the yields were the same as 01 . The average yearly $\mathrm{N}$ removal with harvested crops was $84 \mathrm{~kg} \mathrm{~N} \mathrm{ha}^{-1}$ in 01 and $83 \mathrm{~kg} \mathrm{Nha}^{-1}$ in 02 . To further improve the yield performance of the organic systems, the results indicate that $\mathrm{N}$ management should be improved to the organic crops. Their yield reductions compared to the conventional system was found not to be caused by pests and damages, whereas the $\mathrm{N}$ content was lower of some of the organic crops.

The organic systems were tested during the period 2006-2009, which is not long enough to test long term sustainability. Based on nutrient balances it is clear that especially $\mathrm{O} 2$ and $\mathrm{O} 3$ will need to find sources of $\mathrm{P}$ and $\mathrm{K}$ to balance what is removed, as the fertility building crop strategy primarily improve $\mathrm{N}$ husbandry. However, a farmer practicing such systems will be free to find fertilizers as mineral sources or waste products with available $\mathrm{P}$ and $\mathrm{K}$, which can be used even if they have no or little $\mathrm{N}$ effect. A farmer practicing a system like $\mathrm{O} 1$ on the other hand, will need to import fertilizers with a high $\mathrm{N}$ effect, which may be difficult or expensive to get in competition with other organic farmers.

Regarding nitrogen, the results indicate that the 01 system may actually not be sustainable, as the amount of fertilizer $\mathrm{N}$ added to the system is almost identical to the amount harvested. There will be further $\mathrm{N}$ input through atmospheric deposition (c. $20 \mathrm{~kg} \mathrm{Nha}^{-1}$ ), but also $\mathrm{N}$ losses in terms of leaching and denitrification, and an $\mathrm{N}$ balance including all factors is likely to show a net loss of $\mathrm{N}$ from the $\mathrm{O} 1$ system. The $\mathrm{N}$ balance of $\mathrm{O} 2$ and $\mathrm{O} 3$ is harder to analyze. Much more $\mathrm{N}$ is harvested than what is added with fertilizer, but at the same time $\mathrm{N}$ is also added through $\mathrm{N}$ fixation of the green manures growing after the cereals, and the $\mathrm{N}$ leaching loss is lower than in 01 . In another experiment (Thorup-Kristensen, unpublished data) similarly undersown green manure of white clover, black medick and kidney vetch contained on average $190 \mathrm{~kg} \mathrm{~N} \mathrm{ha}^{-1}$ in November compared to $75 \mathrm{~kg} \mathrm{~N} \mathrm{ha}^{-1}$ on average across non-legume species, indicating an $\mathrm{N}$ fixation of more than c. $115 \mathrm{~kg} \mathrm{Nha}^{-1}$. If this was the case also in the present experiment, the $\mathrm{N}$ fixation of the green manures in $\mathrm{O} 2$ and $\mathrm{O} 3$ almost precisely match the reduced $\mathrm{N}$ input with fertilizer compared to $\mathrm{O} 1$. As $\mathrm{N}$ leaching loss was clearly lower in $\mathrm{O} 2$ and $\mathrm{O3}$, this would lead to an improved overall $\mathrm{N}$ balance and higher degree of sustainability of these two systems compared to O1. The increased input of organic matter adding to the soil C and $\mathrm{N}$ pool may also point towards $\mathrm{O} 2$ and $\mathrm{O} 3$ as more nitrogen sustainable systems than 01 , though to what extent cannot be evaluated here.

\section{Conclusion}

- Yield loss in organic compared to conventional systems could be maintained at a moderate level of on average less than $20 \%$, but it varied strongly depending on crop species.

- Pest and disease damage to vegetable crops was not systematically different among the conventional and the three organic systems.

- Nutrient management could be improved strongly in organic systems by intensive use of fertility building crops, which also reduced nitrogen losses to the environment strongly.

- The use of fertility building crops in 5 of 8 years in the rotation almost doubled the root exploitation of the soil volume.

- When looking at the soil $\mathrm{N}$ and nutrient balance of the systems the main differences were not observed in the comparison of conventional and organic systems, but in the comparison of systems with and without intensive use of fertility building crops, whereas the organic system without fertility building crops resembled the conventional system.

\section{Acknowledgements}

This work was supported by ICROFS (International Centre for Research in Organic Food Systems) through the FØJO III program. We thank the skilful technical staff involved in the project, especially Jørgen Villebro for an incredible overview.

\section{References}

Askegaard, M., Olesen, J.E., Rasmussen, I.A., Kristensen, K., 2011. Nitrate leaching from organic arable crop rotations is mostly determined by autumn field management. Agric. Ecosyst. Environ. 142 (3-4), 149-160.

Aronsson, H., Torstensson, G., Bergström, L., 2007. Leaching and crop uptake of N, P and $\mathrm{K}$ from organic and conventional cropping systems on a clay soil. Soil Use Manage. 23, 71-81.

Birkhofer, K., Bezemer, T.M., Bloem, J., Bonkowski, M., Christensen, S., Dubois, B., Ekelund, F., Fließbach, A., Gunst, L., Hedlund, K., Mäder, P., Mikola, J., Robin, C., Setälä, H., Tatin-Froux, F., Van der Putten, W.H., Scheu, S., 2008. Long-term organic farming fosters below and aboveground biota: implications for soil quality, biological control and productivity. Soil Biol. Biochem. 40, 2297-2308.

Bosshard, C., Sørensen, P., Frossard, E., Dubois, D., Mäder, P., Nanzer, S., Oberson, A., 2009. Nitrogen use efficiency of ${ }^{15} \mathrm{~N}$-labelled sheep manure and mineral fertiliser applied to microplots in long-term organic and conventional cropping systems. Nutr. Cycl. Agroecosyst. 83, 271-287.

Båth, B., Kristensen, H.L., Thorup-Kristensen, K., 2008. Root pruning reduces root competition and increases crop growth in a living mulch cropping system. J. Plant Interact. 3, 211-221.

Canadell, J., Jackson, R.B., Ehleringer, J.R., Mooney, H.A., Sala, O.E., Schulze, E.D., 1996. Maximum rooting depth of vegetation types at the global scale. Oecologia 108 , 583-595.

Cox, T.S., Van Tassel, D.L., Cox, C.M., Dehaan, L.R., 2010. Progress in breeding perennial grains. Crop Pasture Sci. 61, 513-521.

Dangour, A.D., Dodhia, S.K., Hayter, A., Allen, E., Lock, K., Uauy, R., 2009. Nutritional quality of organic foods: a systematic review. Am. J. Clin. Nutr. 90, 680-685.

Doltra, J., Lægdsmand, M., Olesen, J.E., 2011. Cereal yield and quality as affected by nitrogen availability in organic and conventional arable crop rotations: a combined modeling and experimental approach. Eur. J. Agro. 34, 83-95.

Dresbøll, D.B., Bjørn, G.K., Thorup-Kristensen, K., 2008. Yields and the extent and causes of damage in cauliflower, bulb onion, and carrot grown under organic or conventional regimes. J. Horticult. Sci. Biotechnol. 83 (6), 770-776.

Eyre, M.D., Sanderson, R.A., Shotton, P.N., Leifert, C.,2009. Investigating the effects of crop type, fertility management and crop protection on the activity of beneficial invertebrates in an extensive farm management comparison trial. Ann. Appl. Biol. 155, 267-276.

Hansen, E.M., Munkholm, L.J., Melander, B., Olesen, J.E., 2010. Can non-inversion tillage and straw retainment reduce $\mathrm{N}$ leaching in cereal-based crop rotations? Soil Tillage Res. 109, 1-8.

Hogg, B.N., Bugg, R.L., Daane, K.M., 2011. Attractiveness of common insectary and harvestable floral resources to beneficial insects. Biol. Control 56, 76-84.

Gardner, J.B., Drinkwater, L.E., 2009. The fate of nitrogen in grain cropping systems: a meta-analysis of ${ }^{15} \mathrm{~N}$ field experiments. Ecol. Appl. 19, 2167-2184.

Jayasundara, S., Wagner-Riddle, C., Parkin, G., Bertoldi, P.v., Warland, J., Kay, B., Voroney, P., 2007. Minimizing nitrogen losses from a corn-soybean-winter wheat rotation with best management practices. Nutr. Cycl. Agroecosyst. 79, 141-159.

Jones, G.A., Sieving, K.E., 2006. Intercropping sunflower in organic vegetables to augment bird predators of arthropods. Agric. Ecosyst. Environ. 117, 171-177.

Kristensen, H.L., Thorup-Kristensen, K., 2004. Root growth and nitrate uptake of three different catch crops in deep soil layers. Soil Sci. Soc. Am. J. 68, 529-537.

Kristensen, H.L. Thorup-Kristensen, K., 2007. Effects of vertical distribution of soil inorganic nitrogen on root growth and subsequent nitrogen uptake by field vegetable crops. Soil Use Manage. 23, 338-347.

Leifert, C., Rembialkowska, E., Nielson, J.H., Cooper, J.M., Butler, G., Lueck, L., 2007. Effects of organic and 'low input' production methods on food quality and safety. In: Niggli, U., Leifert, C., Alföldi, T., Lück, L., Willer, H., Frick (Eds.), Improving Sustainability in Organic and Low Input Food Production Systems. Research Institute of Organic Farming FiBL, Switzerland, pp. 75-95.

Liedgens, M., Frossard, E., Richner, W., 2004. Interactions of maize and Italian ryegrass in a living mulch system: (2) Nitrogen and water dynamics. Plant Soil 259, 243-258.

Mäder, P., Fließbach, A., Dubois, D., Gunst, L., Fried, P., Niggli, U., 2002. Soil fertility and biodiversity in organic farming. Science $296,1694-1697$.

Meyling, N.V., Thorup-Kristensen, K., Eilenberg, J., 2011. Below- and aboveground abundance and distribution of fungal entomopathogens in experimental conventional and organic cropping systems. Biol. Control 59 (2), 180-186.

Müller-Schärer, H., 1996. Interplanting ryegrass in winter leek: effect on weed control, crop yield and allocation of N-fertilizer. Crop Protect. 15, 641-648.

Sun, G.W., Coffin, D.P., Lauenroth, W.K., 1997. Comparison of root distributions of species in north american grasslands using gis. J. Veget. Sci. 8, 587-596.

Thorup-Kristensen, K., 1999. An organic vegetable crop rotation aimed at selfsufficiency in nitrogen. In: J.E. Olesen, R. Eltun, M.J. Gooding, E.S. Jensen, U. Köpke. Danish Research Centre for Organic Farming, pp. 133-140. 
Thorup-Kristensen, K., Magid, J., Jensen, L.S., 2003. Catch crops and green manures as biological tools in nitrogen management in temperate zones. Adv. Agron. 79 227-302.

Thorup-Kristensen, K., 2006a. Effect of deep and shallow root systems on the dynamics of soil inorganic N during 3-year crop rotations. Plant Soil 288, 233-248.

Thorup-Kristensen, K., 2006b. Root growth and nitrogen uptake of carrot, early cabbage, onion and lettuce following a range of green manures. Soil Use Manage. 22, 29-38.

Thorup-Kristensen, K., Cortasa, M.S., Loges, R., 2009. Winter wheat roots grow twice as deep as spring wheat roots, is this important for $\mathrm{N}$ uptake and $\mathrm{N}$ leaching losses? Plant Soil 322, 101-114.

Thorup-Kristensen, K., Dresbøll, D.B., 2010. Incorporation time of nitrogen catch crops influences the N effect for the succeeding crop. Soil Use Manage. 26, 27-35.
Tonitto, C., David, M.B., Drinkwater, L.E., 2006. Replacing bare fallows with cover crops in fertilizer-intensive cropping systems: A meta-analysis of crop yield and N dynamics. Agric. Ecosyst. Environ. 112, 58-72.

Torstensson, G., Aronsson, H., Bergström, L., 2006. Nutrient use efficiencies and leaching of organic and conventional cropping systems in Sweden. Agron. J. 98 , 603-615.

Sørensen, J.N., Thorup-Kristensen, K., 2003. Undersowing legume crops for green manuring of lettuce. Biol. Agric. Hortic. 21, 399-414.

Vanek, S., Wien, H.C., Rangarajan, A., 2005. Time of interseeding of lana vetch and winter rye cover strips determines competitive impact on pumpkins grown using organic practices. HortScience 40, 1716-1722.

Wehrmann, J., Scharpf, H., 1979. Der Mineralstickstoffgehalt des Bodens als Maßstab für den Stickstoffdüngerbedarf (Nmin-Methode). Plant Soil 52, 109-126. 